\title{
Expression profiling of genes regulated by TGF-beta: Differential regulation in normal and tumour cells
}

\author{
Prathibha Ranganathan ${ }^{1}$, Animesh Agrawal ${ }^{1}$, Raghu Bhushan ${ }^{1}$, \\ Aravinda K Chavalmane ${ }^{1}$, Ravi Kiran Reddy Kalathur ${ }^{1}$, Takashi Takahashi ${ }^{2}$ \\ and Paturu Kondaiah*1
}

\author{
Address: ${ }^{1}$ Department of Molecular Reproduction, Development and Genetics, Indian Institute of Science, Bangalore 560012, India and ${ }^{2}$ Division \\ of Molecular Carcinogenesis, Centre for Neurological Diseases and Cancer, Nagoya University Graduate School of Medicine, Japan \\ Email: Prathibha Ranganathan - pratiba@mrdg.iisc.ernet.in; Animesh Agrawal - animesh.agrawal@gmail.com; \\ Raghu Bhushan - raghubhushanin@yahoo.co.in; Aravinda K Chavalmane - aravi_ck@yahoo.com; Ravi Kiran Reddy Kalathur - ravi@titus.u- \\ strasbg.fr; Takashi Takahashi - tak@med.nagoya-u.ac.jp; Paturu Kondaiah* - paturu@mrdg.iisc.ernet.in \\ * Corresponding author
}

Published: II April 2007

BMC Genomics 2007, 8:98 doi:10.1 186/147|-2164-8-98

This article is available from: http://www.biomedcentral.com/I47I-2164/8/98

(C) 2007 Ranganathan et al; licensee BioMed Central Ltd.

This is an Open Access article distributed under the terms of the Creative Commons Attribution License (http://creativecommons.org/licenses/by/2.0), which permits unrestricted use, distribution, and reproduction in any medium, provided the original work is properly cited.
Received: 7 November 2006

Accepted: II April 2007

\begin{abstract}
Background: TGF-beta is one of the key cytokines implicated in various disease processes including cancer. TGF-beta inhibits growth and promotes apoptosis in normal epithelial cells and in contrast, acts as a pro-tumour cytokine by promoting tumour angiogenesis, immune-escape and metastasis. It is not clear if various actions of TGF-beta on normal and tumour cells are due to differential gene regulations. Hence we studied the regulation of gene expression by TGF-beta in normal and cancer cells.

Results: Using human $19 \mathrm{~K}$ cDNA microarrays, we show that 1757 genes are exclusively regulated by TGF-beta in A549 cells in contrast to 733 genes exclusively regulated in HPLID cells. In addition, 267 genes are commonly regulated in both the cell-lines. Semi-quantitative and real-time qRT-PCR analysis of some genes agrees with the microarray data. In order to identify the signalling pathways that influence TGF-beta mediated gene regulation, we used specific inhibitors of p38 MAP kinase, ERK kinase, JNK kinase and integrin signalling pathways. The data suggest that regulation of majority of the selected genes is dependent on at least one of these pathways and this dependence is celltype specific. Interestingly, an integrin pathway inhibitor, RGD peptide, significantly affected TGFbeta regulation of Thrombospondin I in A549 cells.

Conclusion: These data suggest major differences with respect to TGF-beta mediated gene regulation in normal and transformed cells and significant role of non-canonical TGF-beta pathways in the regulation of many genes by TGF-beta.
\end{abstract}

\section{Background}

TGF- $\beta$ is a multifunctional cytokine that plays important patho-physiological roles in mammals. There are three mammalian isoforms that are involved in several develop- mental processes as has been shown by the knock-out mice models [1]. TGF- $\beta$ has a major role to play in the initiation and progression of cancer. This is supported by several studies which have shown defects in various com- 
ponents of the TGF- $\beta$ signalling pathway in many cancers [2]. TGF- $\beta$ has a dual role in carcinogenesis [3]. Initially it acts as a tumour suppressor and causes growth arrest of epithelial cells and cells in the early stages of cancer [4]. But in an established tumour, TGF- $\beta$ exerts an effect which is favourable for the survival, progression and metastasis of the tumour $[5,6]$ by promoting epithelial-mesenchymal transition (EMT), angiogenesis and escape from immune surveillance [7]. Studies using mouse models have shown that an intact TGF- $\beta$ signalling is essential for the metastasis of breast cancer $[8,9]$. These observations indicate that the normal epithelial cells show differential response to TGF- $\beta$ as compared to the tumour they give rise to. Supporting this, it has been shown that prostate tumour cells show invasion in response to TGF- $\beta$ and not non-tumourigenic cells [10]. Differential gene expression mediated by TGF- $\beta$ has been reported in tumour cells and normal cells. For example, in response to TGF- $\beta$, tumour cells show increase in the production of proteases and down regulation of the inhibitors of proteases, whereas this is not observed in the normal cells [11-14]. However, there is no clear understanding of the mechanism (s) responsible for differential responses of various cell types to TGF- $\beta$. Since a role for TGF- $\beta$ has been established in several pathological conditions, this pathway is a very attractive target for therapeutic intervention. This requires identification of targets of TGF- $\beta$ in different cell-types and their mechanism of regulation, particularly in untransformed and transformed cells. In this study, we show differential regulation of several genes by TGF- $\beta$ in two different cell-lines, HPL1D and A549 and also propose a significant role for the MAP kinase pathway in TGF- $\beta$ mediated gene regulations.

\section{Results \\ Gene expression profiling of HPLID and A549 cells in response to TGF- $\beta$}

To identify the TGF- $\beta$ regulated genes in normal and tumour cells, we chose HPL1D and A549 cells. HPL1D is an immortalized lung epithelial cell-line that is growth inhibited by TGF- $\beta$, similar to many epithelial cells [15]. A549 is a lung adenocarcinoma cell-line that has been known to respond to TGF- $\beta$ treatment [16]. The cells were treated with human recombinant TGF- $\beta 1$ for 1,4 and 12 hours and the RNAs extracted from these cells were used for microarray experiments using human $19 \mathrm{k}$ arrays. Genes which were either up ( $>1.3$ fold) or down regulated ( $<0.33$ fold) at any one of the time points have been considered as regulated by TGF- $\beta$ in the respective cellline. In HPL1D, 1000 genes were regulated by TGF- $\beta$ treatment and of these, 917 genes were up regulated and 83 genes were down regulated. In A549, 2024 genes were regulated by TGF- $\beta$ and of these, 1714 genes were up regulated and 310 genes were down regulated by TGF- $\beta$ treatment. The $\log _{2}$ transformed data of the genes regu- lated by TGF- $\beta$ in HPL1D and A549 cells are shown as hierarchical cluster diagrams (Fig. 1a \&1b). The expression profiling data of HPL1D and A549 in response to TGF- $\beta$ has been submitted to Gene Expression Omnibus (accession number- GSE7436).

\section{Comparison of gene expression profiles of HPLID and A549 in response to TGF- $\beta$}

When the gene expression profiles of HPL1D and A549 cell-lines in response to TGF- $\beta 1$ were compared, it was found that 267 genes were regulated in both the cell-lines in a similar manner but with different kinetics. The list of genes regulated commonly in both HPL1D and A549 is shown in additional file 1 (Table S1). A hierarchical cluster diagram is shown in figure $2 \mathrm{a}$ and a Venn diagram depicting the number of genes commonly and differentially regulated in A549 and HPL1D are shown in figure 2b. 1757 genes are exclusively regulated by TGF- $\beta$ in A549 cells, (see additional file 2 Table S2) and 733 genes are exclusively regulated by TGF- $\beta$ in HPL1D cells (see additional file 3, Table S3). Representative clusters of each of the sub-classes of genes are shown in figure $2 \mathrm{c}$.

\section{Validation of microarray results by $q R T-P C R$}

The microarray data have been validated by real time and semi-quantitative RT-PCR. TMEPA, TGFBIP, IGFBP7, Integrin $\alpha \mathrm{V}$, TSP-1, MMP2 and TGM2 were studied by real time qRT-PCR as described in the methods. The primer sequences used for qRT-PCR are shown in table 1. Any gene is considered as regulated by TGF- $\beta$ if qRT-PCR results showed $>$ two fold regulation as compared to untreated cells. As shown in figure 3 and 4, TMEPA, TGFBIP and MMP2 are regulated by TGF- $\beta 1$ in both HPL1D and A549 cell-lines. In HPL1D, induction of TGFBIP and TMEPA by TGF- $\beta$ is seen after 4 hours of treatment and increases with prolonged incubation. The induction of MMP2 by TGF- $\beta$ is seen 6 hours onwards, whereas, there is no regulation of the genes IGFBP7, TSP-1, TGM2 after TGF- $\beta$ treatment. Integrin $\alpha \mathrm{V}$, showed a 1.8 fold regulation after 24 hours of treatment with TGF- $\beta$. In A549, the induction of all these genes except TGM2 is observed after 4 hours of treatment and increase progressively with time, whereas, the induction of TGM2 increases till 12 hours and then declines. In addition, regulation of few other genes by TGF- $\beta$ such as fibronectin 1, ZF36, S100A2, T $\beta$ RI, ACTA2, T-plastin, keratin 7 and v-jun were assessed by semi-quantitative RT-PCR (See additional file 4, Fig. S1A). The data suggest that all these genes are regulated by 1.5 2.0 fold in HPL1D cells (See additional file 4, Fig. S1B). However, in A549 cells, the regulation of ZF36, ACTA2, Keratin 7, T $\beta$ RI and v-jun is $>2.0$ fold whereas, FN1, Tplastin and S100A2 is 1.5-2.0 fold (See additional file 4, Fig. S1C). 

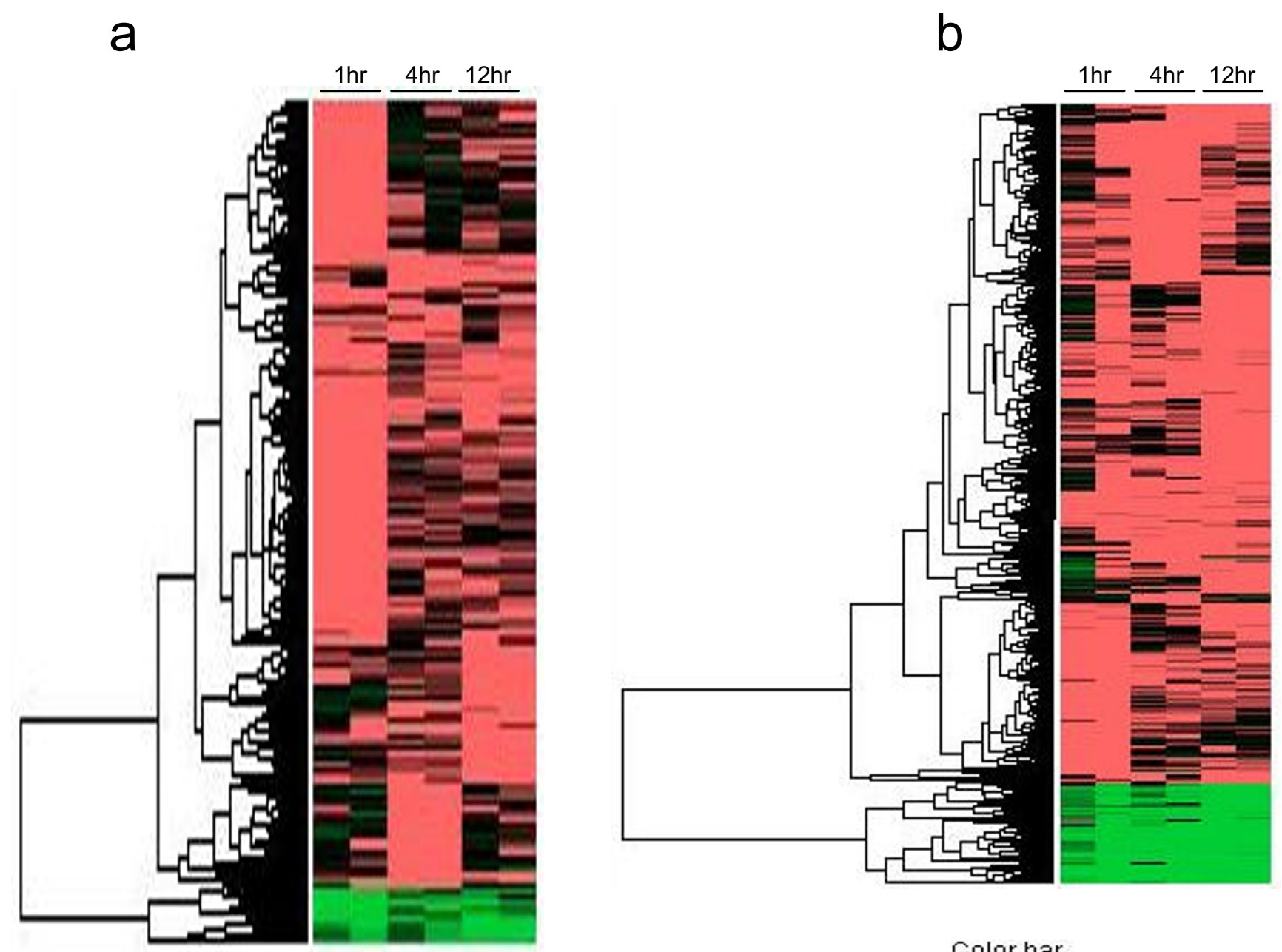

\section{Color bar}

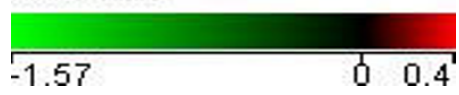

Figure I

Hierarchical clustering of genes regulated by TGF- $\beta$ in (a) HPLID and (b) A549 cells. The genes regulated by TGF$\beta$ (described in materials and methods) were clustered using Avadis 3.3 Prophetic software. The data was clustered on rows by one way complete linkage - hierarchical clustering using Euclidean distance metric. Microarrays have been done in duplicate on RNAs isolated from cells after I, 4 and I 2 hours of treatment with TGF- $\beta$ with paired controls at every time point. The dendrogram on the left shows the different clusters into which the TGF- $\beta$ regulated genes segregated. Red indicates genes induced by TGF- $\beta$ treatment, green indicates genes repressed by TGF- $\beta$ treatment and black suggests no regulation.

\section{Functional categories of genes regulated by TGF- $\beta$ in HPLID and A549}

The lists of the regulated genes were fed into DAVID database (database for annotation, visualization and integrated discovery [17]. Based on the functions of the genes assigned by DAVID, genes were classified into the following categories. In HPL1D, TGF- $\beta$ regulated genes belong to (a) regulation of actin cytoskeleton (table 2), (b) Focal adhesion (table 3) and (c) Wnt signalling pathways (table 4). In A549, TGF- $\beta$ modulated genes belong to (a) MAP kinase signalling (table 5), (b) tight junction (table 6), (c) adherans junction (table 7) (d) focal adhesion (table 8) (e) insulin signalling (table 9 ) (f) regulation of actin cytoskeleton (table 10) and (g) Wnt signalling (table 11).

\section{Effect of inhibiting the MAPK pathways on the TGF- $\beta$ mediated gene regulation}

TGF- $\beta$ modulates gene expression through phosphorylation of SMAD proteins. However, several studies show a role for MAP kinase pathway in TGF- $\beta$ mediated gene regulation both in a SMAD dependent and independent manner [18-20]. Hence, inhibitors of MAP kinase path- 

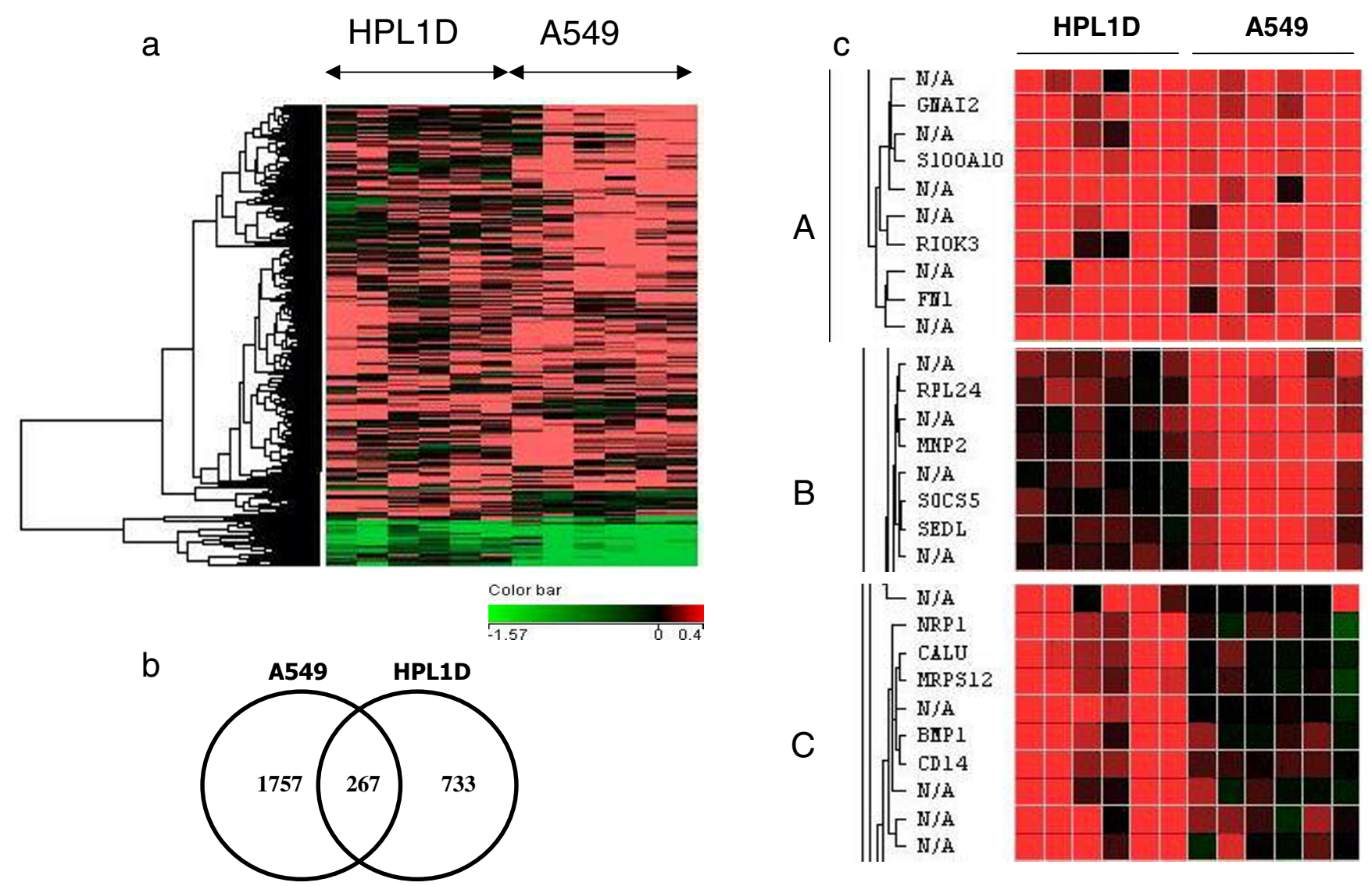

Figure 2

Comparison of genes regulated by TGF- $\beta$ in HPLID and A549 cells. a, Hierarchical clustering of genes regulated by TGF$\beta$ in HPLID and A549 cells Genes regulated by TGF- $\beta$ in HPLID and A549 cells were clustered using Avadis 3.3 software. For this comparison only those genes for which expression values are available in both the cell-lines have been considered. The dendrogram on the left shows different clusters of genes segregated according to the pattern of regulation in the two cell-lines. b, Venn diagram showing the genes regulated by TGF- $\beta$ either common or exclusively to the cell-lines and c, Expanded clusters showing sub-classes of genes regulated by TGF- $\beta$ in HPLID and A549 (derived from Figure 2a); A, Genes regulated by TGF- $\beta$ in both HPLID and A549 (267 genes); B, Genes regulated by TGF- $\beta$ in A549 and not in HPLID (I757 genes); C, Genes regulated by TGF- $\beta$ in HPLID and not in A549 (733 genes).

way components, SB203580 (p38), PD98059 (ERK) and JNK inhibitor 1-L form were used to assess the role of $\mathrm{p} 38$, ERK and JNK pathways in the regulation of gene expression by TGF- $\beta$. In A549 cells, regulation of IGFBP7 by TGF- $\beta$ is independent of the $\mathrm{p} 38$, ERK and the JNK pathways. Induction of Integrin $\alpha \mathrm{V}, \mathrm{MMP} 2, \mathrm{TMEPA}$ and TGM2 by TGF- $\beta$ is partially dependent on the ERK pathway; and MMP2, TGFBIP, TGM2 and TSP- 1 regulation by TGF- $\beta$ is partially dependent on the p38 pathway. The induction of Integrin $\alpha \mathrm{V}$ is partially affected by blocking the JNK pathway (Fig. 5). In HPL1D cells, Intgerin $\alpha \mathrm{V}, \mathrm{MMP} 2$ and TGFBIP regulation by TGF- $\beta$ is affected by blocking the p38 MAP kinase pathway, none of the gene regulations by TGF- $\beta$ seem to be affected by blocking the ERK pathway and the induction of TMEPA by TGF- $\beta$ is dependent on the JNK pathway (Fig. 6).

\section{Effect of blocking the Integrin-linked signalling pathway in A549 cells}

Apart from the various signalling pathways and phenomena modulated by TGF- $\beta$ in both normal and tumour cells, a pathway which is likely be differentially regulated is the Integrin- $\alpha \mathrm{V}$ linked signalling pathway. Integrin $\alpha \mathrm{V}$ is induced by TGF- $\beta$ in A549 cells to about 3.5 fold as compared to 1.8 fold in HPL1D. Integrin $\alpha \mathrm{V}$ is known to mediate some actions of TGF- $\beta[21,22]$. In order to test if some of the genes regulated by TGF- $\beta$ are due to activation of Integrin $\alpha \mathrm{V}$, the activation of this pathway was blocked 
Table I: List of genes selected for validation by real-time RT-PCR

\begin{tabular}{|c|c|c|c|}
\hline \multirow[t]{2}{*}{ Gene Name } & \multicolumn{2}{|c|}{ Fold regulation in microarray } & \multirow[t]{2}{*}{ Primer sequences } \\
\hline & HPLID cells & A549 cells & \\
\hline TGF- $\beta$ induced protein 68 kDa (TGFBIP) & 1.8 & 2.8 & $\begin{array}{l}\text { F 5' tgtgtgctgaagccatcgttg } 3^{\prime} \\
\text { R 5' ccggcttgtctgaaaaggtca } 3^{\prime}\end{array}$ \\
\hline Trans membrane prostate androgen induced RNA (TMEPA) & 1.5 & 3.08 & $\begin{array}{l}\text { F5'ttcattccctgtcctcattgg3' } \\
\text { R5'gcacaacagccatggaatca3' }\end{array}$ \\
\hline Insulin like growth factor binding protein 7 (IGFBP7) & 1.49 & 2.72 & $\begin{array}{l}5^{\prime} \text { ggtccttccatagtgacgcc } 3^{\prime} \\
5^{\prime} \text { tctgaatggccaggttgtcc } 3^{\prime}\end{array}$ \\
\hline Matrix metalloprotease 2 (MMP2) & 1.0 & 1.32 & $\begin{array}{l}5^{\prime} \text { ctgatggcacccatttacacc } 3^{\prime} \\
5^{\prime} \text { gectcgtataccgcatcaatc } 3^{\prime}\end{array}$ \\
\hline Transglutaminase 2 (TGM2) & 1.2 & 3.27 & $\begin{array}{l}5^{\prime} \text { ccatgaccagaacagcaacct3' } \\
5^{\prime} \text { tgacctccgcaaagacaaag } 3^{\prime}\end{array}$ \\
\hline Thrombospondin I (TSP-I) & I.I & 2.24 & $\begin{array}{l}5^{\prime} \text { ccggcgtgaagtgtactagcta } 3^{\prime} \\
5^{\prime} \text { tgcacttggcgttcttgtt } 3^{\prime}\end{array}$ \\
\hline Integrin $\alpha \mathrm{V}$ & 1.1 & 2.73 & $\begin{array}{l}5^{\prime} \text { caggcttgcaacccattct } 3^{\prime} \\
5^{\prime} \text { cctggcgagtttggttttct } 3^{\prime}\end{array}$ \\
\hline RPL35a & & & $\begin{array}{l}5^{\prime} \text { gggtacagcatcactcgga } 3^{\prime} \\
5^{\prime} \text { acgcccgagatgaaacag } 3^{\prime}\end{array}$ \\
\hline
\end{tabular}

The genes were selected based on any or both of the following criteria. I. Genes that showed differential regulation between cell-lines and show maximum regulation in at least one of the cell-lines, 2 . Genes that showed regulation in the array and are known as TGF- $\beta$ regulated genes in other studies. The primer sequences are shown $5^{\prime}$ to $3^{\prime}$ and $F$ and $R$ denote forward and reverse primers respectively.

by treating the cells with $500 \mu \mathrm{g} / \mathrm{ml}$ of GRGDNP peptide, a known Integrin pathway inhibitor, prior to treatment with TGF- $\beta$. It was found that the induction of TSP-1, which is a TGF- $\beta$ regulated gene only in A549 cells, is
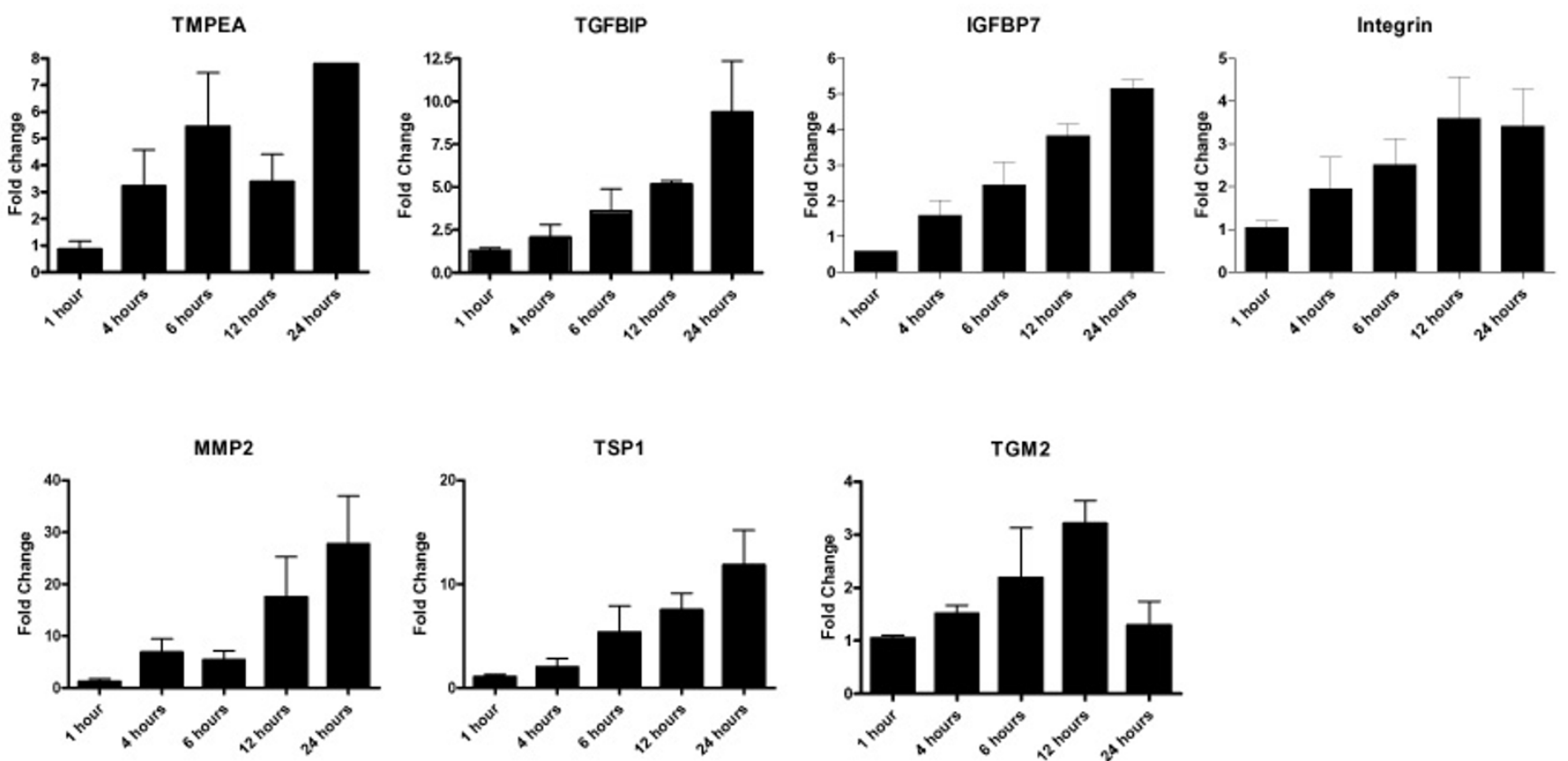

Figure 3

qRT-PCR analyses of selected genes (TMEPA, TGFBIP, IGFBP7, Integrin $\alpha$, TSP-I, MMP2, TGM2) with respect to TGF- $\beta$ treatment in $\mathbf{A 5 4 9}$ cells. The cells were grown to $90 \%$ confluence, washed with serum free medium and treated with $5 \mathrm{ng} / \mathrm{ml}$ TGF- $\beta$ I for I, 4, 6, I 2 and 24 hours along with untreated controls at each time-point. Two microgram of total RNA from each treatment was reverse transcribed and cDNA equivalent to IOng total RNA was used for the PCR reactions. The graphs represent the fold change over untreated controls after normalization with the expression of RPL35a. The bars show mean \pm SD of two experiments of the PCR reactions done in duplicates. 

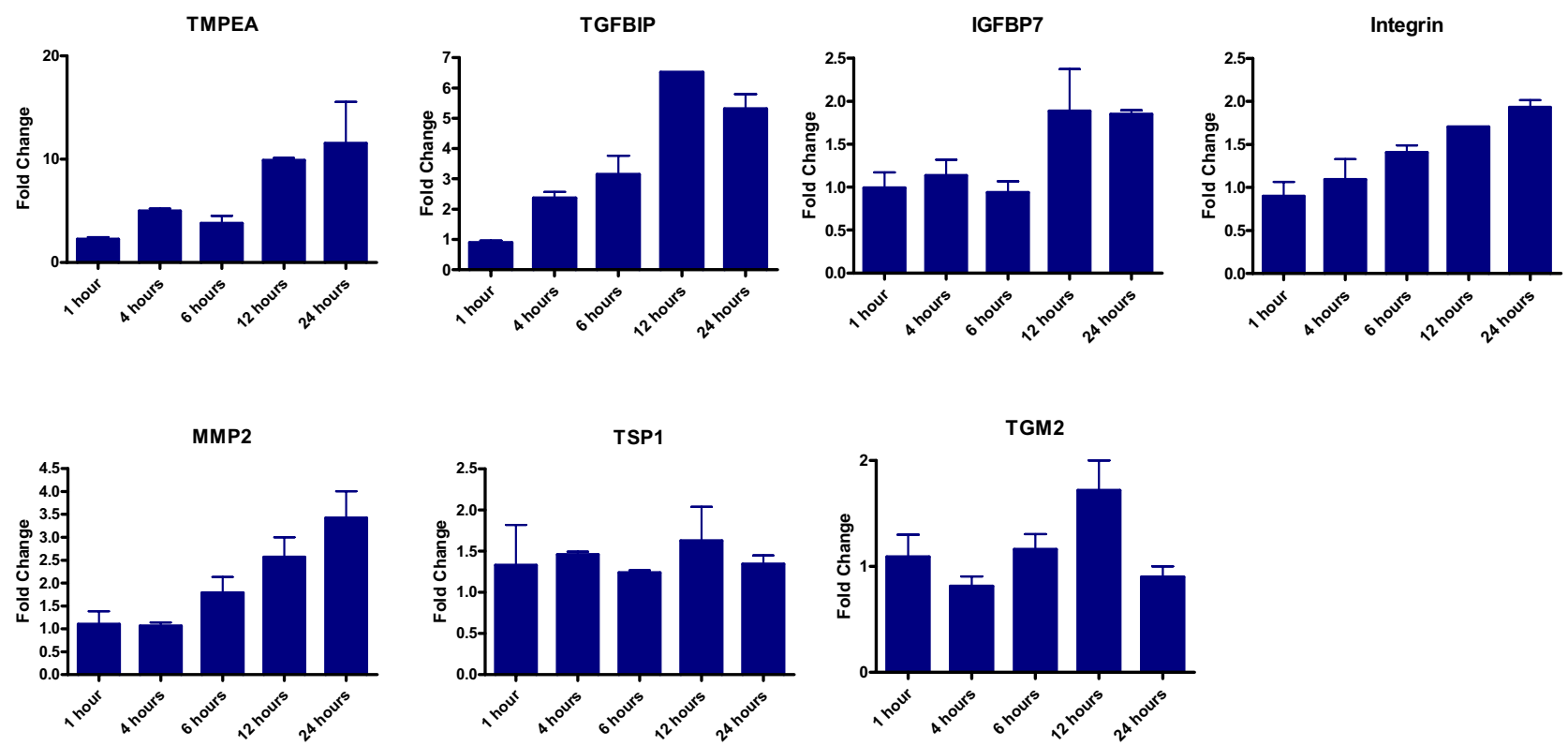

\section{Figure 4}

qRT-PCR analyses of selected genes (TMEPA, TGFBIP, IGFBP7, Integrin $\alpha$, TSP-I, MMP2, TGM2) with respect to TGF- $\beta$ treatment in HPLID cells. The cells were grown to $90 \%$ confluence, washed with serum free medium and treated with $5 \mathrm{ng} / \mathrm{ml}$ TGF- $\beta$ I for I, 4, 6, I 2 and 24 hours along with untreated controls at each time-point. Two microgram of total RNA from each treatment was reverse transcribed and cDNA equivalent to IOng total RNA was used for the PCR reactions. The graphs represent the fold change over untreated controls after normalization with the expression of RPL35a. The bars show mean \pm SD of two experiments of the PCR reactions done in duplicates.

affected by blocking the integrin-linked signalling pathway (Figure 7 and Figure 8). Blocking this pathway had no effect on the regulation of the other genes tested. This suggests that the Integrin pathway is also responsible for differential regulation of some genes by TGF- $\beta$ in the two cell-types, HPL1D and A549.

\section{Discussion}

Most actions of TGF- $\beta$ are brought about by regulation of gene expression. The genes, which are regulated and the way they are regulated are largely dependent on the celltype under consideration. Over the past few years, there have been several independent transcriptome analyses of cells in response to TGF- $\beta$ treatment. In cells of epithelial origin like human keratinocytes and mouse breast epithelial cells, TGF- $\beta$ modulates genes involved in EMT $[23,24]$. In lung fibroblasts and A549 cells, TGF- $\beta$ treatment results in the induction of extracellular matrix genes which are responsible for fibrosis as in the case of idiopathic pulmonary and alveolar epithelial fibrosis $[25,26]$. Studies using various cells such as cervical cancer cells, corneal epithelial cells, rat intestinal epithelial cells, and dermal fibroblasts show that regulation of gene expression by TGF- $\beta$ is cell-type specific [27-30]. Considering the dual role of TGF- $\beta$ on normal and transformed cells, wherein it confers growth inhibition and apoptosis to normal epithelial cells but aids growth and metastasis of tumour cells [4-7], it is essential to identify the genes and/or biochemical pathways regulated by TGF- $\beta$ in normal and transformed cells. An understanding of these differences may allow identification of therapeutic targets for diseases involving TGF- $\beta$ signalling pathway.

With this aim, expression profiling of genes in response to TGF- $\beta$ was performed in a lung adenocarcinoma cell-line (A549) and a matched immortalized lung epithelial cellline (HPL1D). The experimental design includes treatment of the respective cells with $5 \mathrm{ng} / \mathrm{ml}$ TGF- $\beta$ in serum free conditions for 1,4 and $12 \mathrm{hrs}$ and extract RNA for microarray experiments. In our experiments, we have used two arrays for each RNA (time point) and hence essentially these are technical duplicates. As a consequence although duplicate arrays were performed for each time point, effectively the sample size equals to 1 at each time point since they are technical duplicates. Due to this, it is possible that many changes that are seen could be due to variations in the experimental protocols, rather than real biological differences. To overcome this, we have performed qRT-PCR validation of several genes on biological replicates that agrees with the microarray data for the respective genes. Our data showed similar regulation of 267 genes in HPL1D and A549 cells by TGF- $\beta$. This sug- 
Table 2: TGF- $\beta$ regulated genes (I7) in HPLID involved in regulation of actin cytoskeleton

\begin{tabular}{|c|c|c|c|c|}
\hline Acc No & DAVID Gene Name & I hr & $4 \mathrm{hr}$ & $12 \mathrm{hr}$ \\
\hline W20454 & FIBRONECTIN I & $1.23 \pm 0$ & $1.36 \pm 0.04$ & $2.1 \pm 0.19$ \\
\hline H58824 & DIAPHANOUS HOMOLOG I (DROSOPHILA) & $0.84 \pm 0.1$ & $1.57 \pm 0.19$ & $1 \pm 0.11$ \\
\hline N46724 & RHO GUANINE NUCLEOTIDE EXCHANGE FACTOR (GEF) 7 & $1.4 \pm 0.07$ & $0.96 \pm 0.21$ & $1 \pm 0.07$ \\
\hline AA045207 & ACTIN RELATED PROTEIN 2/3 COMPLEX, SUBUNIT 5, I6KDA & $1.3 \pm 0.09$ & $1.3 \pm 0.23$ & $1.55 \pm 0.12$ \\
\hline BM924824 & $\begin{array}{l}\text { RAS-RELATED C3 BOTULINUM TOXIN SUBSTRATE I (RHO FAMILY, SMALL GTP } \\
\text { BINDING PROTEIN RACI) }\end{array}$ & $1.11 \pm 0.08$ & $1.14 \pm 0.03$ & $1.55 \pm 0.07$ \\
\hline BQ0I7489 & ACTININ, ALPHA I & $1.42 \pm 0.03$ & $1.02 \pm 0.11$ & $1.53 \pm 0.2$ \\
\hline $\mathrm{H} 73128$ & INTEGRIN, BETA 5 & $1.06 \pm 0.03$ & $1.21 \pm 0.03$ & $1.47 \pm 0.11$ \\
\hline W56632 & CDI4 ANTIGEN & $1.46 \pm 0$ & $1.15 \pm 0$ & $1.45 \pm 0.06$ \\
\hline AA046597 & INTEGRIN, BETA 4 & $1.63 \pm 0.14$ & $1.57 \pm 0$ & $1.43 \pm 0.07$ \\
\hline $\mathrm{H} 23109$ & FIBROBLAST GROWTH FACTOR I (ACIDIC) & $1.55 \pm 0.1$ & $0.94 \pm 0.08$ & $1.42 \pm 0.2$ \\
\hline AA0I0526 & GLUCOCORTICOID RECEPTOR DNA BINDING FACTOR I & $1.37 \pm 0.26$ & $1.29 \pm 0.07$ & $1.36 \pm 0.02$ \\
\hline W67710 & $\begin{array}{l}\text { PLATELET-DERIVED GROWTH FACTOR BETA POLYPEPTIDE (SIMIAN SARCOMA } \\
\text { VIRAL (V-SIS) ONCOGENE HOMOLOG) }\end{array}$ & $1.53 \pm 0.07$ & $1.17 \pm 0.02$ & $1.2 \pm 0.01$ \\
\hline AA037763 & WAS PROTEIN FAMILY, MEMBER 2 & $1.41 \pm 0.08$ & $1.08 \pm 0.02$ & $1.18 \pm 0.05$ \\
\hline W39107 & RAS HOMOLOG GENE FAMILY, MEMBER A & $1.37 \pm 0.05$ & $1.07 \pm 0.04$ & $1.14 \pm 0.16$ \\
\hline AL598940 & MYOSIN, LIGHT POLYPEPTIDE I, ALKALI; SKELETAL, FAST & $1.36 \pm 0.05$ & $1.06 \pm 0.12$ & $1.07 \pm 0.02$ \\
\hline AAI31272 & INTEGRIN, ALPHA 8 & $1.19 \pm 0$ & $1.38 \pm 0.06$ & $0.96 \pm 0.02$ \\
\hline H83405 & FYVE, RHOGEF AND PH DOMAIN CONTAINING I (FACIOGENITAL DYSPLASIA) & $0.45 \pm 0.01$ & $0.52 \pm 0.17$ & $0.25 \pm 0$ \\
\hline
\end{tabular}

The list in the table shows the regulated genes as revealed by the DAVID tool. The columns show Genbank accession no., gene name, and fold change with respect to untreated controls at I hr, $4 \mathrm{hr}$ and $12 \mathrm{hr}$ time points following TGF- $\beta$ treatment respectively. The regulation shown against each gene is depicted as fold change \pm S.E. with respect to untreated cells. Each experimental value of the duplicates of the respective genes is shown in tables SI and S3 (see additional file I and 3). The number in the parenthesis of the title represents the number of genes in the table.

gests that the genes commonly regulated in both HPL1D and A549 are not tumour specific. Some of these genes were also reported to be regulated by TGF- $\beta$ in other studies using microarray in various cell-types $[23,24,27]$ suggesting that these TGF- $\beta$ regulated genes are not tumour cell specific but generally regulated by TGF- $\beta$. While some 1757 genes are exclusively regulated by TGF- $\beta$ in A549, only 733 genes are exclusively regulated in HPL1D cells. The reasons for this differential response are not known.
However, some of the genes exclusively regulated in A549 such as Integrin $\alpha \mathrm{V}$, thrombospondin 1 , $\alpha 2$ macroglobulin have been shown to aid tumour survival, maintenance and metastasis [31-33]. In contrast, in HPL1D, TGF- $\beta$ regulates tumour suppressor genes like WT1, ECM proteins like collagen which are responsible for arrest of cell growth and apoptosis. This differential gene regulation in normal and tumour cells may explain the dual role of TGF- $\beta$ in carcinogenesis. When the genes

Table 3: TGF- $\beta$ regulated genes (19) in HPLID involved in focal adhesion

\begin{tabular}{|c|c|c|c|c|}
\hline Acc No & DAVID Gene Name & I hr & $4 \mathrm{hr}$ & $12 \mathrm{hr}$ \\
\hline AA031376 & PLACENTAL GROWTH FACTOR, VASCULAR ENDOTHELIAL GROWTH FACTOR-RELATED PROTEIN & $1.18 \pm 0.47$ & $1.36 \pm 0.05$ & $1.16 \pm 0.04$ \\
\hline AA046597 & INTEGRIN, BETA 4 & $1.63 \pm 0.14$ & $1.57 \pm 0$ & $1.43 \pm 0.07$ \\
\hline AAI31272 & INTEGRIN, ALPHA 8 & $1.19 \pm 0$ & $1.38 \pm 0.06$ & $0.96 \pm 0.02$ \\
\hline AW959692 & VASCULAR ENDOTHELIAL GROWTH FACTOR C & $1.15 \pm 0.17$ & $1.34 \pm 0.02$ & $1.44 \pm 0.31$ \\
\hline N74737 & COLLAGEN, TYPE IV, ALPHA 2 & $0.84 \pm 0.01$ & $1 \pm 0.04$ & $1.51 \pm 0.01$ \\
\hline AA030029 & PROTEIN KINASE C, ALPHA & $1.3 \pm 0$ & $1.14 \pm 0.03$ & $1.1 \pm 0.07$ \\
\hline AL079948 & THROMBOSPONDIN I & $0.78 \pm$ & $1.82 \pm 0.09$ & $2.5 \pm 0.1$ \\
\hline $\mathrm{H} 73 \mathrm{I} 28$ & INTEGRIN, BETA 5 & $1.06 \pm 0.03$ & $1.21 \pm 0.03$ & $1.47 \pm 0.11$ \\
\hline BM924824 & RAS-RELATED C3 BOTULINUM TOXIN SUBSTRATE I (RHO FAMILY, SMALL GTP BINDING PROTEIN RACI) & $1.11 \pm 0.08$ & $1.14 \pm 0.03$ & $1.55 \pm 0.07$ \\
\hline BM80I832 & CAVEOLIN I, CAVEOLAE PROTEIN, 22 KDA & $1.09 \pm 0.11$ & $1.4 \pm 0.01$ & $1.47 \pm 0$ \\
\hline W67710 & $\begin{array}{l}\text { PLATELET-DERIVED GROWTH FACTOR BETA POLYPEPTIDE (SIMIAN SARCOMA VIRAL (V-SIS) ONCOGENE } \\
\text { HOMOLOG) }\end{array}$ & $1.53 \pm 0.07$ & $1.17 \pm 0.02$ & $1.2 \pm 0.01$ \\
\hline W20454 & FIBRONECTIN I & $1.23 \pm 0$ & $1.36 \pm 0.04$ & $2.1 \pm 0.19$ \\
\hline AA029359 & LAMININ, BETA 2 (LAMININ S) & $1.54 \pm 0.06$ & $1.17 \pm 0.08$ & $1.02 \pm 0.06$ \\
\hline W39107 & RAS HOMOLOG GENE FAMILY, MEMBER A & $1.37 \pm 0.05$ & $1.07 \pm 0.04$ & $1.14 \pm 0.16$ \\
\hline AA04330I & COLLAGEN, TYPE IV, ALPHA I & $1.4 \pm 0.19$ & $1.52 \pm$ & $1.52 \pm 0.03$ \\
\hline BQ0I7489 & ACTININ, ALPHA I & $1.42 \pm 0.03$ & $1.02 \pm 0.11$ & $1.53 \pm 0.2$ \\
\hline AA0I0526 & GLUCOCORTICOID RECEPTOR DNA BINDING FACTOR I & $1.37 \pm 0.26$ & $1.29 \pm 0.07$ & $1.36 \pm 0.02$ \\
\hline RI4058 & PROTEIN KINASE C, BETA I & $1.34 \pm 0.02$ & $0.81 \pm 0.1$ & $0.94 \pm 0.03$ \\
\hline H58824 & DIAPHANOUS HOMOLOG I (DROSOPHILA) & $0.84 \pm 0.1$ & $1.57 \pm 0.19$ & $1 \pm 0.11$ \\
\hline
\end{tabular}

For description see legend of table 2 
Table 4: TGF- $\beta$ regulated genes (I5) in HPLID involved in wnt signaling

\begin{tabular}{|c|c|c|c|c|}
\hline Acc No & DAVID Gene Name & I hr & $4 \mathrm{hr}$ & $12 \mathrm{hr}$ \\
\hline N92026 & PROTEIN PHOSPHATASE 3 (FORMERLY 2B), CATALYTIC SUBUNIT, BETA ISOFORM (CALCINEURIN A BETA) & $0.92 \pm 0.06$ & $1.31 \pm 0.01$ & $1.05 \pm 0.11$ \\
\hline H82025 & PRICKLE-LIKE I (DROSOPHILA) & $1.79 \pm 0.18$ & $1.17 \pm 0.02$ & $1.21 \pm$ \\
\hline AA044665 & F-BOX AND WD-40 DOMAIN PROTEIN II & $1.24 \pm 0.18$ & $1.14 \pm$ & $1.42 \pm 0.08$ \\
\hline AA030029 & PROTEIN KINASE C, ALPHA & $1.3 \pm 0$ & $1.14 \pm 0.03$ & $1.1 \pm 0.07$ \\
\hline AA203216 & PROTEIN PHOSPHATASE 2 (FORMERLY 2A), REGULATORY SUBUNIT B (PR 52), BETA ISOFORM & $1.26 \pm 0$ & $1.07 \pm 0.2$ & $1.5 \pm 0.04$ \\
\hline H79065 & PRICKLE-LIKE 2 (DROSOPHILA) & $1.38 \pm 0.07$ & $1.04 \pm 0.28$ & $1.01 \pm 0.14$ \\
\hline BM921730 & PROTEIN PHOSPHATASE 2 (FORMERLY 2A), REGULATORY SUBUNIT A (PR 65), BETA ISOFORM & $1.48 \pm 0.01$ & $1.19 \pm 0.06$ & $1.17 \pm 0.01$ \\
\hline R23027 & CASEIN KINASE I, ALPHA I & $1.28 \pm 0.08$ & $1.46 \pm 0.01$ & $1.26 \pm 0.08$ \\
\hline BM924824 & RAS-RELATED C3 BOTULINUM TOXIN SUBSTRATE I (RHO FAMILY, SMALL GTP BINDING PROTEIN RACI) & $1.11 \pm 0.08$ & $1.14 \pm 0.03$ & $1.55 \pm 0.07$ \\
\hline $\mathrm{BM} 311217$ & WINGLESS-TYPE MMTV INTEGRATION SITE FAMILY, MEMBER 4 & $1.26 \pm 0.09$ & $1 \pm 0.06$ & $1.34 \pm 0.02$ \\
\hline W86518 & C-TERMINAL BINDING PROTEIN 2 & $1.33 \pm 0.01$ & $1.35 \pm 0.24$ & $1.13 \pm 0.07$ \\
\hline $\mathrm{H} 70045$ & CALCIUM/CALMODULIN-DEPENDENT PROTEIN KINASE (CAM KINASE) II GAMMA & $1.48 \pm 0.16$ & $1.1 \pm 0.01$ & $1.16 \pm 0.05$ \\
\hline W39107 & RAS HOMOLOG GENE FAMILY, MEMBER A & $1.37 \pm 0.05$ & $1.07 \pm 0.04$ & $1.14 \pm 0.16$ \\
\hline BE618078 & CALCIUM/CALMODULIN-DEPENDENT PROTEIN KINASE (CAM KINASE) II BETA & $1.58 \pm 0.02$ & $0.86 \pm 0.05$ & $1.02 \pm 0.1$ \\
\hline RI4058 & PROTEIN KINASE C, BETA I & $1.34 \pm 0.02$ & $0.81 \pm 0.1$ & $0.94 \pm 0.03$ \\
\hline
\end{tabular}

For description see legend of table 2

Table 5: TGF- $\beta$ regulated genes (38) in A549 involved in MAP kinase signalling

\begin{tabular}{|c|c|c|c|c|}
\hline Acc No & DAVID Gene Name & I hr & $4 \mathrm{hr}$ & $12 \mathrm{hr}$ \\
\hline H09832 & ACTIVIN A RECEPTOR, TYPE IB & $1.01 \pm 0.17$ & $1.66 \pm 0.29$ & $1.17 \pm 0.06$ \\
\hline N2768I & HEAT SHOCK 70 KDA PROTEIN IA & $1.12 \pm 0.01$ & $1.46 \pm 0.18$ & $1.42 \pm 0.08$ \\
\hline $\mathrm{H} 73255$ & MITOGEN-ACTIVATED PROTEIN KINASE KINASE KINASE 6 & $0.84 \pm 0.31$ & $1.04 \pm 0.07$ & $1.49 \pm 0.11$ \\
\hline N42722 & GUANINE NUCLEOTIDE BINDING PROTEIN (G PROTEIN), GAMMA I2 & $1.44 \pm 0.04$ & $1.5 \pm 0.09$ & $1.28 \pm 0.17$ \\
\hline AA039598 & RIBOSOMAL PROTEIN S6 KINASE, 90 KDA, POLYPEPTIDE I & $1.16 \pm 0.13$ & $1.21 \pm 0.02$ & $1.32 \pm 0.02$ \\
\hline AA030029 & PROTEIN KINASE C, ALPHA & $1.33 \pm 0.23$ & $1.56 \pm 0.08$ & $1.36 \pm 0.03$ \\
\hline H73472 & CELL DIVISION CYCLE 42 (GTP BINDING PROTEIN, 25 KDA) & $1.24 \pm 0.27$ & $1.33 \pm 0.07$ & $1.56 \pm 0.01$ \\
\hline H62639 & HEAT SHOCK 70 KDA PROTEIN 8 & $1.29 \pm 0.01$ & $1.68 \pm 0.18$ & $1.37 \pm 0$ \\
\hline $\mathrm{H} 23019$ & $\begin{array}{l}\text { TRANSFORMING GROWTH FACTOR, BETA RECEPTOR I (ACTIVIN A RECEPTOR TYPE II-LIKE KINASE, } 53 \\
\text { KDA) }\end{array}$ & $1.09 \pm 0.01$ & $2.53 \pm 0.07$ & $2.11 \pm 0.41$ \\
\hline AA088648 & FIBROBLAST GROWTH FACTOR RECEPTOR I (FMS-RELATED TYROSINE KINASE 2, PFEIFFER SYNDROME) & $1.45 \pm 0.24$ & $1.97 \pm 0.08$ & $1.77 \pm 0.09$ \\
\hline AV747676 & V-AKT MURINE THYMOMA VIRAL ONCOGENE HOMOLOG 3 (PROTEIN KINASE B, GAMMA) & $1.06 \pm 0.13$ & $1.46 \pm 0.05$ & $1.18 \pm 0.01$ \\
\hline Al500475 & RAS GUANYL RELEASING PROTEIN I (CALCIUM AND DAG-REGULATED) & $1.31 \pm 0.05$ & $1.37 \pm 0$ & $1.41 \pm 0.07$ \\
\hline R86053 & NUCLEAR FACTOR OF KAPPA LIGHT POLYPEPTIDE GENE ENHANCER IN B-CELLS 2 (P49/PI00) & $0.99 \pm 0.12$ & $0.9 \pm 0.07$ & $1.44 \pm 0.09$ \\
\hline BE502II2 & RIBOSOMAL PROTEIN S6 KINASE, 90 KDA, POLYPEPTIDE 3 & $0.37 \pm 0.1$ & $0.29 \pm 0.05$ & $0.41 \pm 0.06$ \\
\hline $\mathrm{H} 23109$ & FIBROBLAST GROWTH FACTOR I (ACIDIC) & $0.94 \pm$ & $1.36 \pm 0.01$ & $1.13 \pm 0.05$ \\
\hline AAI 27934 & PROTEIN KINASE, X-LINKED & $1.21 \pm 0.07$ & $1.38 \pm 0.01$ & $1.35 \pm 0.07$ \\
\hline H89206 & PROTEIN KINASE, CAMP-DEPENDENT, CATALYTIC, BETA & $1.18 \pm 0.08$ & $1.42 \pm 0.04$ & $1.25 \pm 0.03$ \\
\hline RI4348 & MITOGEN-ACTIVATED PROTEIN KINASE KINASE KINASE 5 & $1.45 \pm 0.09$ & $1.22 \pm 0.17$ & $1.03 \pm 0.06$ \\
\hline BM924824 & RAS-RELATED C3 BOTULINUM TOXIN SUBSTRATE I (RHO FAMILY, SMALL GTP BINDING PROTEIN RACI) & $1.39 \pm 0$ & $1.41 \pm 0.06$ & $1.28 \pm 0.18$ \\
\hline HII708 & MITOGEN-ACTIVATED PROTEIN KINASE KINASE 4 & $1.38 \pm 0.02$ & $1.54 \pm 0.1$ & $1.24 \pm 0.17$ \\
\hline R3640I & FILAMIN B, BETA (ACTIN BINDING PROTEIN 278) & $0.96 \pm 0.02$ & $1.17 \pm 0.11$ & $1.33 \pm 0.01$ \\
\hline BI758537 & MADS BOX TRANSCRIPTION ENHANCER FACTOR 2, POLYPEPTIDE C (MYOCYTE ENHANCER FACTOR 2C) & $1.77 \pm 0.42$ & $1.25 \pm$ & $1.36 \pm 0.09$ \\
\hline W56249 & ACTIVATING TRANSCRIPTION FACTOR 2 & $1.25 \pm 0.13$ & $1.5 \pm 0.02$ & $1.72 \pm 0.18$ \\
\hline AA034981 & INTERLEUKIN I RECEPTOR, TYPE I & $0.37 \pm 0.08$ & $0.4 \pm 0.02$ & $0.29 \pm 0.04$ \\
\hline AA056664 & V-AKT MURINE THYMOMA VIRAL ONCOGENE HOMOLOG I & $1.34 \pm 0.15$ & $1.44 \pm 0.05$ & $1.36 \pm 0.07$ \\
\hline $\mathrm{H} 20677$ & MITOGEN-ACTIVATED PROTEIN KINASE KINASE KINASE 7 INTERACTING PROTEIN I & $1.13 \pm 0.15$ & $0.96 \pm 0.1$ & $1.6 \pm 0.01$ \\
\hline BM999610 & V-JUN SARCOMA VIRUS I7 ONCOGENE HOMOLOG (AVIAN) & $1.57 \pm 0.26$ & $2.13 \pm 0.01$ & $1.66 \pm 0.18$ \\
\hline BE78I203 & CALCIUM CHANNEL, VOLTAGE-DEPENDENT, ALPHA IG SUBUNIT & $1.13 \pm 0.03$ & $1.02 \pm 0$ & $1.44 \pm 0$ \\
\hline T83272 & RAS P2I PROTEIN ACTIVATOR 2 & $0.96 \pm 0.08$ & $1.12 \pm 0.18$ & $1.33 \pm 0.02$ \\
\hline T75436 & MITOGEN-ACTIVATED PROTEIN KINASE IO & $1.16 \pm 0.17$ & $1.22 \pm 0.05$ & $1.37 \pm 0.07$ \\
\hline W70006 & CELL DIVISION CYCLE 25B & $1.47 \pm 0.1$ & $1.15 \pm 0.05$ & $1.38 \pm 0.08$ \\
\hline R32409 & PHOSPHOLIPASE A2, GROUP V & $1.14 \pm 0.27$ & $1.27 \pm 0.01$ & $1.5 \pm 0.07$ \\
\hline $\begin{array}{l}\text { AW96187 } \\
3\end{array}$ & CALCIUM CHANNEL, VOLTAGE-DEPENDENT, GAMMA SUBUNIT 4 & $1.45 \pm 0.15$ & $1.23 \pm 0.17$ & $1.02 \pm 0$ \\
\hline BI752921 & PLATELET-DERIVED GROWTH FACTOR RECEPTOR, BETA POLYPEPTIDE & $1.43 \pm 0.09$ & $1.03 \pm 0.02$ & $1.09 \pm 0.07$ \\
\hline BQ055308 & RIBOSOMAL PROTEIN L4 & $1.44 \pm 0.05$ & $1.26 \pm 0.04$ & $1.43 \pm 0.08$ \\
\hline RI4058 & PROTEIN KINASE C, BETA I & $1.54 \pm 0.06$ & $1.08 \pm 0.01$ & $1.15 \pm 0$ \\
\hline BQ016II7 & V-FOS FBJ MURINE OSTEOSARCOMA VIRAL ONCOGENE HOMOLOG & $1.48 \pm 0.26$ & $1.44 \pm 0.04$ & $1.29 \pm 0.06$ \\
\hline W05234 & CALCIUM CHANNEL, VOLTAGE-DEPENDENT, BETA 3 SUBUNIT & $1.4 \pm 0.07$ & $1.15 \pm 0.05$ & $1.27 \pm 0$ \\
\hline
\end{tabular}

The list in the table shows the regulated genes as revealed by the DAVID tool. The columns show Genbank accession no., gene name, and fold change with respect to untreated controls at I hr, $4 \mathrm{hr}$ and $\mathrm{I} 2 \mathrm{hr}$ time points following TGF- $\beta$ treatment respectively. The regulation shown against each gene is depicted as fold change \pm S.E. with respect to untreated cells. Each experimental value of the duplicates of respective genes is shown in tables SI and S2 (see additional files I and 2 ). The number in the parenthesis of the title represents the number of genes in the table. 
Table 6: TGF- $\beta$ regulated genes (2I) in A549 involved in tight junction

\begin{tabular}{|c|c|c|c|c|}
\hline Acc No & DAVID Gene Name & I hr & $4 \mathrm{hr}$ & $12 \mathrm{hr}$ \\
\hline AA027986 & PROTEIN PHOSPHATASE 2 (FORMERLY 2A), CATALYTIC SUBUNIT, ALPHA ISOFORM & $1.24 \pm 0.15$ & $1.65 \pm 0.03$ & $1.34 \pm 0.11$ \\
\hline $\mathrm{H} 8040 \mathrm{I}$ & V-YES-I YAMAGUCHI SARCOMA VIRAL ONCOGENE HOMOLOG I & $0.3 \pm 0.19$ & $0.2 \pm 0.07$ & $0.29 \pm 0.01$ \\
\hline R52046 & ACTININ, ALPHA 4 & $1.26 \pm 0.68$ & $1.21 \pm$ & $1.81 \pm 0.21$ \\
\hline AA030029 & PROTEIN KINASE C, ALPHA & $1.33 \pm 0.23$ & $1.56 \pm 0.08$ & $1.36 \pm 0.03$ \\
\hline BE738680 & RAS HOMOLOG GENE FAMILY, MEMBER A & $1.24 \pm 0.11$ & $1.4 \pm 0.06$ & $1.51 \pm 0.03$ \\
\hline $\mathrm{H} 73472$ & CELL DIVISION CYCLE 42 (GTP BINDING PROTEIN, 25 KDA) & $1.24 \pm 0.27$ & $1.33 \pm 0.07$ & $1.56 \pm 0.01$ \\
\hline N92643 & CALCIUM/CALMODULIN-DEPENDENT SERINE PROTEIN KINASE (MAGUK FAMILY) & $1.31 \pm$ & $1.45 \pm 0.01$ & $1.03 \pm 0.01$ \\
\hline $\mathrm{B} 1828016$ & SPECTRIN, ALPHA, NON-ERYTHROCYTIC I (ALPHA-FODRIN) & $1.33 \pm 0.08$ & $1.38 \pm 0.01$ & $1.93 \pm 0.04$ \\
\hline AV747676 & V-AKT MURINE THYMOMA VIRAL ONCOGENE HOMOLOG 3 (PROTEIN KINASE B, GAMMA) & $1.06 \pm 0.13$ & $1.46 \pm 0.05$ & $1.18 \pm 0.01$ \\
\hline AA03I382 & GUANINE NUCLEOTIDE BINDING PROTEIN (G PROTEIN), ALPHA INHIBITING ACTIVITY POLYPEPTIDE 2 & $1.23 \pm 0.04$ & $1.21 \pm 0.05$ & $1.65 \pm 0.21$ \\
\hline RI406I & PAR-3 PARTITIONING DEFECTIVE 3 HOMOLOG (C. ELEGANS) & $1.52 \pm 0.07$ & $1.12 \pm 0.04$ & $1.05 \pm 0$ \\
\hline AA056664 & V-AKT MURINE THYMOMA VIRAL ONCOGENE HOMOLOG I' & $1.34 \pm 0.15$ & $1.44 \pm 0.05$ & $1.36 \pm 0.07$ \\
\hline BI553762 & CATENIN (CADHERIN-ASSOCIATED PROTEIN), ALPHA 2 & $1.36 \pm 0.06$ & $1.17 \pm 0.03$ & $1.88 \pm 0.21$ \\
\hline BM993684 & CORTACTIN & $1.63 \pm 0.07$ & $1.32 \pm 0.11$ & $1.26 \pm 0.08$ \\
\hline AA009869 & ERYTHROCYTE MEMBRANE PROTEIN BAND $4 . I$ (ELLIPTOCYTOSIS I, RH-LINKED) & $1.19 \pm 0.13$ & $1.21 \pm 0.05$ & $1.39 \pm 0.02$ \\
\hline AA058385 & TIGHT JUNCTION PROTEIN 2 (ZONA OCCLUDENS 2) & $1.35 \pm 0.15$ & $1.36 \pm 0.02$ & $1.16 \pm 0.18$ \\
\hline Al375078 & KIAAI634 PROTEIN & $1.48 \pm 0.02$ & $1.25 \pm 0.03$ & $1.04 \pm 0.01$ \\
\hline BM97899। & MEMBRANE ASSOCIATED GUANYLATE KINASE, WW AND PDZ DOMAIN CONTAINING 2 & $1.1 \pm 0.05$ & $1.15 \pm 0$ & $1.47 \pm 0.05$ \\
\hline N43838 & ERYTHROCYTE MEMBRANE PROTEIN BAND 4.I-LIKE 3 & $1.4 \pm 0.08$ & $1.15 \pm 0.14$ & $1.15 \pm 0.09$ \\
\hline BQ017489 & ACTININ, ALPHA I & $1.57 \pm 0.22$ & $1.24 \pm 0.1$ & $1.5 \pm 0.1$ \\
\hline RI4058 & PROTEIN KINASE C, BETA I & $1.54 \pm 0.06$ & $1.08 \pm 0.01$ & $1.15 \pm 0$ \\
\hline
\end{tabular}

For description see legend of table 5

regulated by TGF- $\beta$ in these two cell-lines were categorized based on their annotated functions, it was found that signalling pathways like MAP kinase, focal adhesion, Wnt signalling are regulated by TGF- $\beta$ in both the cell-lines. On the other hand, Integrin $\alpha \mathrm{V}$ was found to be differentially regulated in A549 and HPL1D cells.

TGF- $\beta$ actions on cells are to a large extent are carried out by the phosphorylation of SMAD $2 / 3$ by activated TGF- $\beta$ type I receptor upon TGF- $\beta$ signalling. Several genes that are transcriptionally regulated by TGF- $\beta$ contain a SMAD complex binding element (SBE). However, many genes are reported to be regulated by TGF- $\beta$ through an AP1 element [34,35]. Using SMAD2/SMAD3 knock out fibroblast cell-lines, SMAD 2 and 3 independent actions of TGF- $\beta$ have been reported earlier [36]. In addition, SMAD independent signalling by TGF- $\beta$ mediated by other pathways like the MAP kinases namely the p38, ERK and the JNK pathways is also reported [18-20,37-40]. Activation of the p38 and the JNK pathways by TGF- $\beta$ involves a TGF- $\beta$ activated kinase called TAK1 (reviewed in $[41,42]$ ). However, the ERK pathway activation by TGF- $\beta$ is not well characterized. Also, cross talk between SMAD mediated signalling and PKC pathway has been reported [43]. Another pathway that has been implicated in TGF- $\beta$ actions is the integrin signalling pathway. It has been shown that activation of integrin $\beta 1$ along with $\alpha \mathrm{V}$ is important for the EMT mediated by TGF- $\beta$ [22]. Although, Integrin $\alpha \mathrm{V}$ is known to mediate some actions of TGF- $\beta$ in some celltypes $[21,22,44-46]$, the genes regulated by TGF- $\beta$ through this pathway have not been characterized. Our data suggest substantial induction of integrin $\alpha \mathrm{V}$ by TGF$\beta$ in only A549 cells and marginally in HPL1D cells. This could be an important difference between these two celllines for the regulation of gene expression mediated by TGF- $\beta$ via this pathway. In order to understand the mechanism of regulation of some of the previously validated genes identified in the microarray experiments, specific inhibitors for the three branches of the MAP kinase pathway namely the p38, the ERK and the JNK pathways were used prior to TGF- $\beta$ treatment of the cells and expression of these genes was studied by real time qRT-PCR estimation. The results suggested that in A549 cells, active MAP kinase pathways are involved in the regulation of more number of genes with relatively higher magnitude by TGF$\beta$ as compared to HPL1D cells (Fig. 5\&6). There could be several reasons for this observation: 1] It is known that the MAP kinases are constitutively active in highly malignant cells due to autocrine activation of MAP kinase pathways [47], PI3K/Akt pathways [48], constitutive activation or amplification of receptors such as EGFR, PDGFR etc., mechanisms [49]. MAP kinase pathway involvement in the TGF- $\beta$ mediated gene regulation is well established and the constitutive activation of MAP kinase pathway in transformed cells could be one of the reasons for more number of genes regulated by TGF- $\beta$ in A549 cells. 2] It could be due to activation of Integrin pathway in transformed cells. It has been reported that Integrin mediated FAK/ILK activation is required for the regulation of EMT $[22,50]$. Our data suggesting regulation of Thrombospondin 1 which is an EMT marker [51] by TGF- $\beta$ via integrin pathway, could be an example of this pathway's importance in TGF- $\beta$ mediated gene regulation at least with respect to genes that mediate EMT. Taken together, our data highlights the importance of MAP kinase and integrin pathways in the regulation of majority of genes 

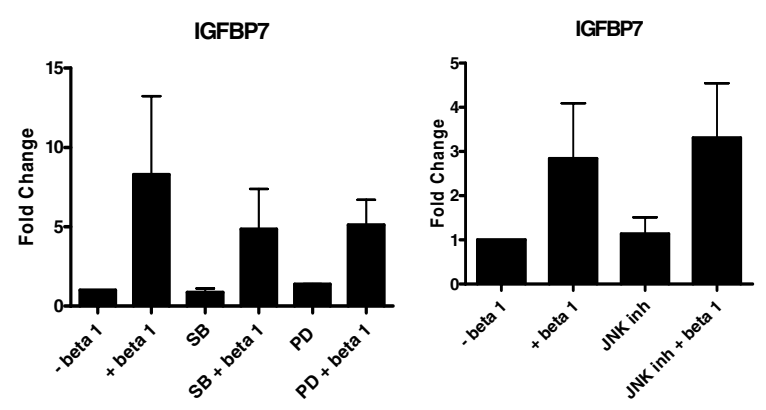

Integrin

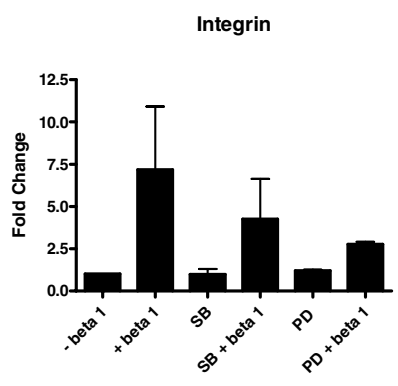

MMP2
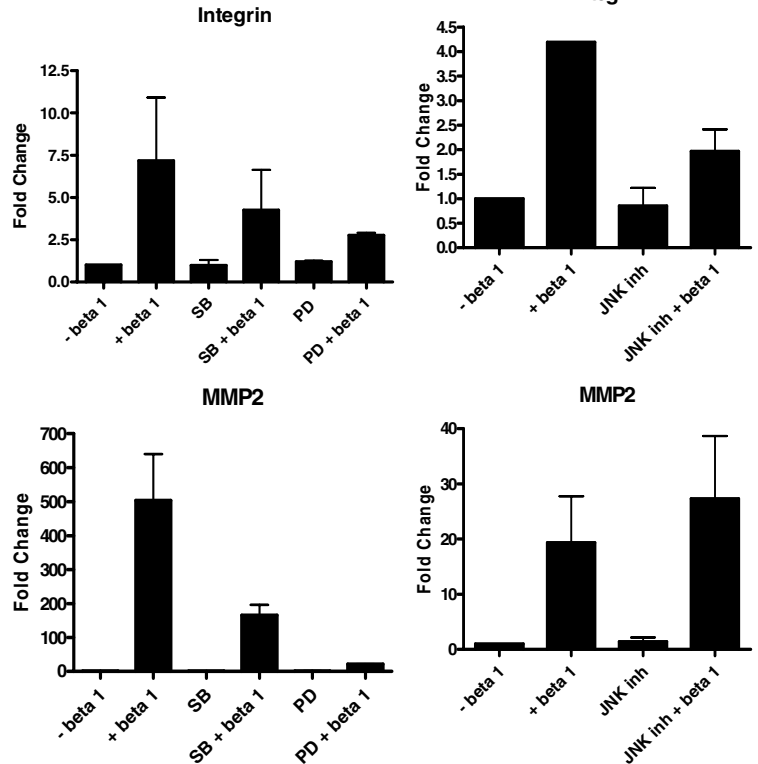

MMP2

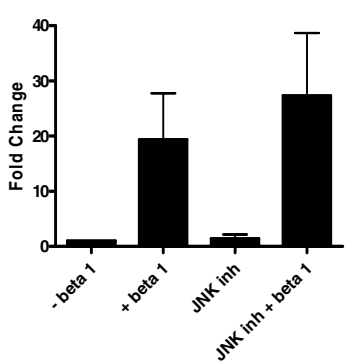

TSP1

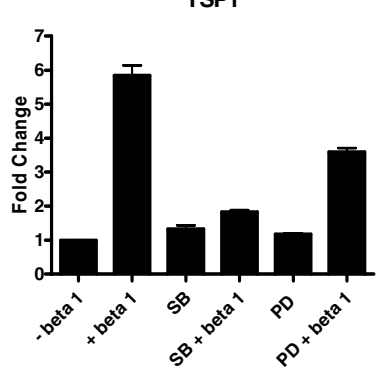

TGFBIP

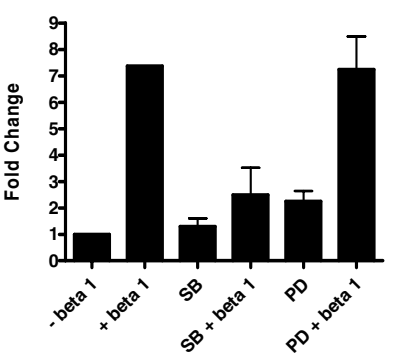

TMEPA

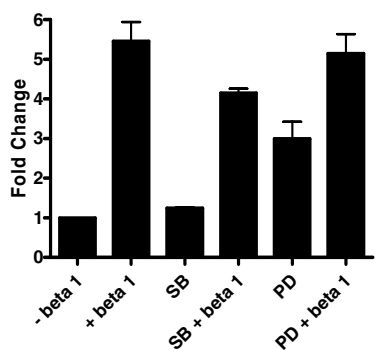

TSP1

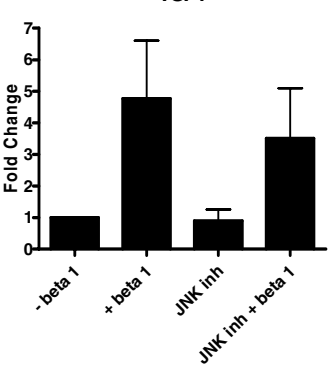

TGFBIP

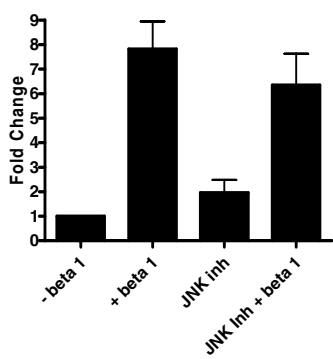

TMEPA

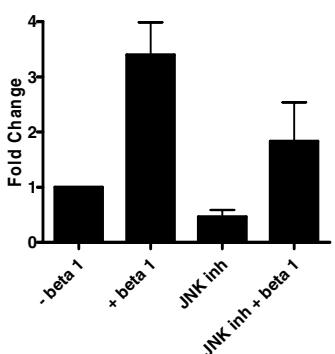

Figure 5

Effect of inhibition of the MAP kinase pathways on the regulation of gene expression by TGF- $\beta$ in A549 cells. The cells were grown to $90 \%$ confluence, washed with serum free medium, treated with $10 \mu \mathrm{M}$ p38 inhibitor (SB203580), ERK inhibitor (PD98059) or JNK inhibitor I hour prior to treatment with TGF- $\beta$. The cells were harvested after 18 hours following TGF- $\beta$ treatment and processed for qRT-PCR as described in Figure 3.

by TGF- $\beta$ at least in transformed cells. The role of SMAD pathway in the regulation of these genes that are affected by the MAP kinase and integrin $\alpha \mathrm{V}$ inhibitors is not known. It is possible that some of these regulations that depend on non-SMAD pathways may also need activated SMAD pathway. One difference between normal and tumour cells could be the absence of an intact SMAD signalling pathway in tumour cells. However, in A549 cells, no defects in the SMAD pathway have been reported. In addition, we confirmed the presence of intact SMAD pathway in A549 cells by SMAD dependent regulation of promoter activity by TGF- $\beta$ (See additional file 5, Fig. S2). Based on our data, we propose that activated MAP kinase pathway could be one of the essential determining factors for the various differential actions of TGF- $\beta$ in tumour cells.
A major question that remains to be addressed is whether the TGF- $\beta$ mediated differential gene expression patterns in HPL1D and A549 cells is due to the distinct phenotypic characteristics of the respective cell-lines. From the previous studies, it is well established that TGF- $\beta$ influences the growth and apoptosis of untransformed epithelial cells such as lung epithelial cells [52]. At least the growth inhibition by TGF- $\beta$ has been less sensitive in the presence of serum [53] suggesting that activation of signalling pathways by serum may antagonize TGF- $\beta$ mediated growth inhibition. Most apoptosis studies using TGF- $\beta$ have also been carried out in minimal serum conditions (0.2-0.5 $\%)$. It remains to be established if apoptotic cell death mediated by TGF- $\beta$ could be reversed in the presence of serum although it can be speculated that reversal of growth inhibition may allow survival of cells. One of the most important actions of the serum is activation of 
Table 7: TGF- $\beta$ regulated genes (2I) in A549 involved in adherans junction

\begin{tabular}{|c|c|c|c|c|}
\hline Acc No & DAVID Gene Name & I hr & $4 \mathrm{hr}$ & $12 \mathrm{hr}$ \\
\hline $\mathrm{H} 78804$ & SMAD, MOTHERS AGAINST DPP HOMOLOG 3 (DROSOPHILA) & $1.22 \pm 0.09$ & $1.36 \pm 0.02$ & $1.15 \pm 0.06$ \\
\hline H09832 & ACTIVIN A RECEPTOR, TYPE IB & $1.01 \pm 0.17$ & $1.66 \pm 0.29$ & $1.17 \pm 0.06$ \\
\hline $\mathrm{H} 8040 \mathrm{I}$ & V-YES-I YAMAGUCHI SARCOMA VIRAL ONCOGENE HOMOLOG I & $0.3 \pm 0.19$ & $0.2 \pm 0.07$ & $0.29 \pm 0.01$ \\
\hline R52046 & ACTININ, ALPHA 4 & $1.26 \pm 0.68$ & $1.21 \pm$ & $1.81 \pm 0.21$ \\
\hline AA029516 & TRANSCRIPTION FACTOR 7-LIKE 2 (T-CELL SPECIFIC, HMG-BOX) & $1.25 \pm 0.02$ & $1.41 \pm 0.02$ & $1.14 \pm 0.2$ \\
\hline BE738680 & RAS HOMOLOG GENE FAMILY, MEMBER A & $1.24 \pm 0.11$ & $1.4 \pm 0.06$ & $1.51 \pm 0.03$ \\
\hline $\mathrm{H} 73472$ & CELL DIVISION CYCLE 42 (GTP BINDING PROTEIN, 25 KDA) & $1.24 \pm 0.27$ & $1.33 \pm 0.07$ & $1.56 \pm 0.01$ \\
\hline $\mathrm{H} 23019$ & $\begin{array}{l}\text { TRANSFORMING GROWTH FACTOR, BETA RECEPTOR I (ACTIVIN A RECEPTOR TYPE II-LIKE } \\
\text { KINASE, } 53 \text { KDA) }\end{array}$ & $1.09 \pm 0.01$ & $2.53 \pm 0.07$ & $2.11 \pm 0.41$ \\
\hline AA088648 & $\begin{array}{l}\text { FIBROBLAST GROWTH FACTOR RECEPTOR I (FMS-RELATED TYROSINE KINASE 2, PFEIFFER } \\
\text { SYNDROME) }\end{array}$ & $1.45 \pm 0.24$ & $1.97 \pm 0.08$ & $1.77 \pm 0.09$ \\
\hline R55I34 & TRANSCRIPTION FACTOR 7-LIKE I (T-CELL SPECIFIC, HMG-BOX) & $1.45 \pm 0.03$ & $1.2 \pm 0.1$ & $1.27 \pm 0.05$ \\
\hline BM3। 4539 & CATENIN (CADHERIN-ASSOCIATED PROTEIN), DELTA I & $1.35 \pm 0.04$ & $1.21 \pm 0.08$ & $1.05 \pm 0.06$ \\
\hline $\mathrm{R}|406|$ & PAR-3 PARTITIONING DEFECTIVE 3 HOMOLOG (C. ELEGANS) & $1.52 \pm 0.07$ & $1.12 \pm 0.04$ & $1.05 \pm 0$ \\
\hline BM924824 & $\begin{array}{l}\text { RAS-RELATED C } 3 \text { BOTULINUM TOXIN SUBSTRATE I (RHO FAMILY, SMALL GTP BINDING PROTEIN } \\
\text { RACI) }\end{array}$ & $1.39 \pm 0$ & $1.41 \pm 0.06$ & $1.28 \pm 0.18$ \\
\hline W24540 & FERM, RHOGEF AND PLECKSTRIN DOMAIN PROTEIN 2 & $1.28 \pm 0.06$ & $1.37 \pm 0.1$ & $1.46 \pm 0.05$ \\
\hline BI553762 & CATENIN (CADHERIN-ASSOCIATED PROTEIN), ALPHA 2 & $1.36 \pm 0.06$ & $1.17 \pm 0.03$ & $1.88 \pm 0.21$ \\
\hline R35I67 & BAII-ASSOCIATED PROTEIN 2 & $1.46 \pm 0.15$ & $0.97 \pm 0.02$ & $1.32 \pm 0.12$ \\
\hline T82805 & PROTEIN TYROSINE PHOSPHATASE, RECEPTOR TYPE, J & $1.49 \pm 0.09$ & $1.35 \pm 0.13$ & $1.19 \pm 0.08$ \\
\hline AA069424 & INSULIN-LIKE GROWTH FACTOR I RECEPTOR & $1.5 \pm 0.09$ & $1.16 \pm 0.07$ & $1.02 \pm 0.05$ \\
\hline N77III2 & IQ MOTIF CONTAINING GTPASE ACTIVATING PROTEIN I & $1.6 \pm 0.35$ & $1.54 \pm 0.13$ & $1.48 \pm 0.04$ \\
\hline BQ017489 & ACTININ, ALPHA I & $1.57 \pm 0.22$ & $1.24 \pm 0.1$ & $1.5 \pm 0.1$ \\
\hline AA005247 & MET PROTO-ONCOGENE (HEPATOCYTE GROWTH FACTOR RECEPTOR) & $1.68 \pm 0.34$ & $1.3 \pm 0.03$ & $1.14 \pm 0.07$ \\
\hline
\end{tabular}

For description see legend of table 5
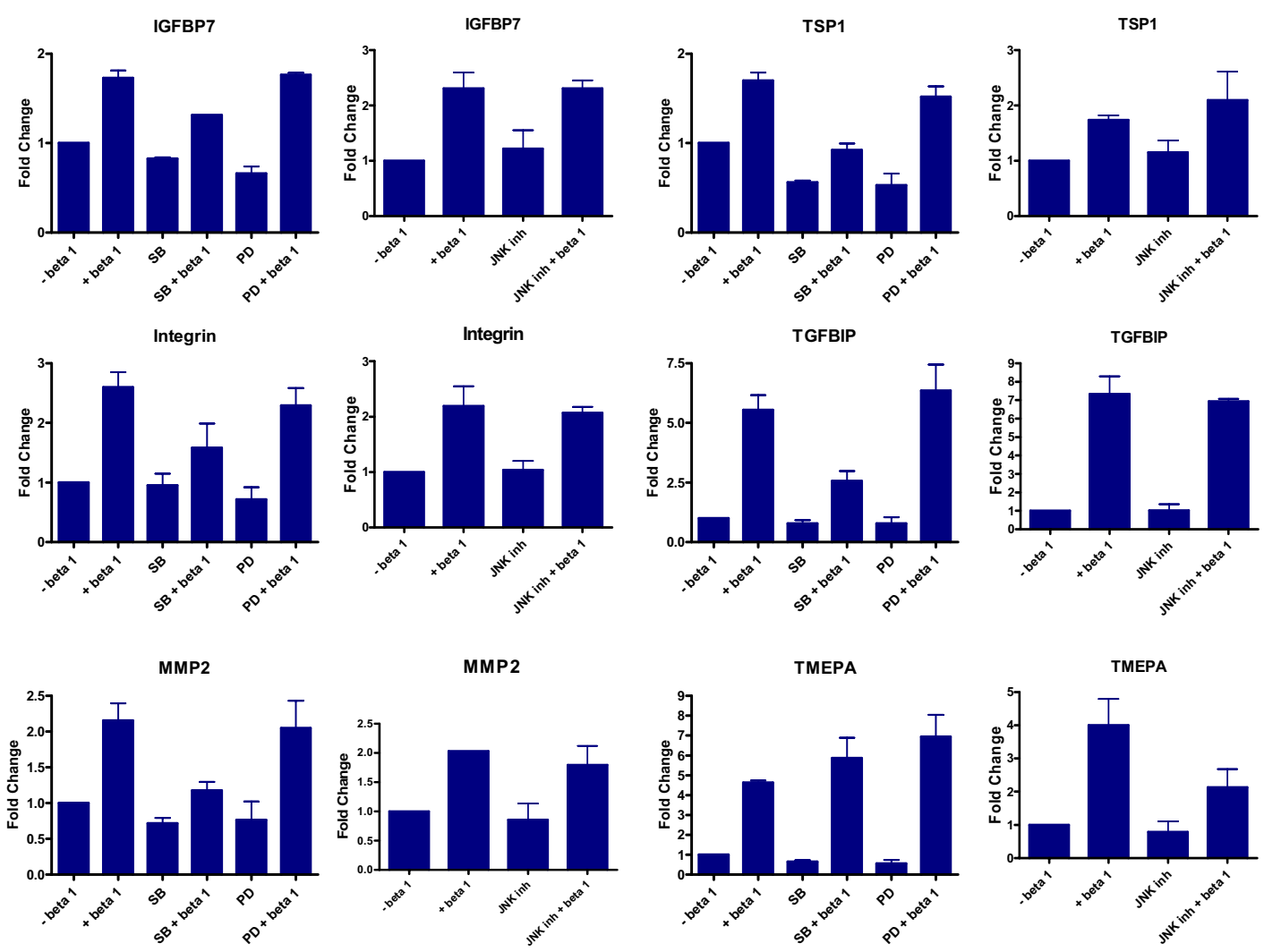

\section{Figure 6}

Effect of inhibition of the MAP kinase pathways on the regulation of gene expression by TGF- $\beta$ in HPLID cells. The cells were grown to $90 \%$ confluence, washed with serum free medium, treated with $10 \mu \mathrm{M}$ p38 inhibitor (SB203580), ERK inhibitor (PD98059) or JNK inhibitor I hour prior to treatment with TGF- $\beta$. The cells were harvested after 18 hours following TGF- $\beta$ treatment and processed for QRT-PCR as described in Figure 3. 
Table 8: TGF- $\beta$ regulated genes (36) in A549 involved in focal adhesion

\begin{tabular}{|c|c|c|c|c|}
\hline Acc No & DAVID Gene Name & I hr & $4 \mathrm{hr}$ & $12 \mathrm{hr}$ \\
\hline N45505 & VAV I ONCOGENE & $0.64 \pm 0.37$ & $0.41 \pm 0.11$ & $0.31 \pm 0.01$ \\
\hline AA046597 & INTEGRIN, BETA 4 & $1.26 \pm 0.21$ & $1.1 \pm 0.19$ & $1.8 \pm 0.18$ \\
\hline R52046 & ACTININ, ALPHA 4 & $1.26 \pm 0.68$ & $1.21 \pm$ & $1.81 \pm 0.21$ \\
\hline AA030029 & PROTEIN KINASE C, ALPHA & $1.33 \pm 0.23$ & $1.56 \pm 0.08$ & $1.36 \pm 0.03$ \\
\hline BE738680 & RAS HOMOLOG GENE FAMILY, MEMBER A & $1.24 \pm 0.11$ & $1.4 \pm 0.06$ & $1.51 \pm 0.03$ \\
\hline $\mathrm{H} 73472$ & CELL DIVISION CYCLE 42 (GTP BINDING PROTE IN, 25 KDA) & $1.24 \pm 0.27$ & $1.33 \pm 0.07$ & $1.56 \pm 0.01$ \\
\hline WI7002 & INTEGRIN, ALPHA V (VITRONECTIN RECEPTOR, ALPHA POLYPEPTIDE, ANTIGEN CD5I) & $1.21 \pm 0.06$ & $2.32 \pm 0.29$ & $2.73 \pm 0.28$ \\
\hline AV747676 & V-AKTMURINE THYMOMA VIRAL ONCOGENE HOMOLOG 3 (PROTEIN KINASE B, GAMMA) & $1.06 \pm 0.13$ & $1.46 \pm 0.05$ & $1.18 \pm 0.01$ \\
\hline BM912016 & P2I(CDKNIA)-ACTIVATED KINASE 4 & $1.29 \pm 0.03$ & $1.1 \pm 0.23$ & $1.54 \pm 0.03$ \\
\hline BM008467 & ZYXIN & $0.95 \pm 0.1$ & $1.16 \pm 0.14$ & $1.41 \pm 0.07$ \\
\hline AA037738 & HEPATOCYTE GROWTH FACTOR (HEPAPOIETIN A; SCATTER FACTOR) & $1.43 \pm 0.07$ & $1.36 \pm 0.03$ & $1.06 \pm 0.13$ \\
\hline H89256 & LAMININ, BETA I & $1.44 \pm 0.02$ & $1.4 \pm 0.02$ & $1.12 \pm 0.07$ \\
\hline AA026831 & KINASE INSERT DOMAIN RECEPTOR (A TYPE III RECEPTOR TYROSINE KINASE) & $1.17 \pm 0.1$ & $1.34 \pm 0.02$ & $1.06 \pm 0.01$ \\
\hline BM924824 & RAS-RELATED C3 BOTULINUM TOXIN SUBSTRATE I (RHO FAMILY, SMALL GTP BINDING PROTEIN RACI) & $1.39 \pm 0$ & $1.41 \pm 0.06$ & $1.28 \pm 0.18$ \\
\hline AAI2229| & COLLAGEN, TYPE V, ALPHA 2 & $1.1 \pm 0.08$ & $1.19 \pm 0.13$ & $1.43 \pm 0.11$ \\
\hline R3640I & FILAMIN B, BETA (ACTIN BINDING PROTEIN 278) & $0.96 \pm 0.02$ & $1.17 \pm 0.11$ & $1.33 \pm 0.01$ \\
\hline R20452 & CALPAIN 10 & $1.19 \pm 0.21$ & $1.08 \pm 0.06$ & $1.5 \pm 0.01$ \\
\hline HI5287 & P2I(CDKNIA)-ACTIVATED KINASE 6 & $1.47 \pm 0.08$ & $1.21 \pm 0.05$ & $1.57 \pm 0.04$ \\
\hline W24540 & FERM, RHOGEF AND PLECKSTRIN DOMAIN PROTEIN 2 & $1.28 \pm 0.06$ & $1.37 \pm 0.1$ & $1.46 \pm 0.05$ \\
\hline T39460 & PROTEIN PHOSPHATASE I, CATALYTIC SUBUNIT, ALPHA ISOFORM & $1.35 \pm 0.17$ & $1.38 \pm 0.04$ & $1.49 \pm 0.15$ \\
\hline AA056664 & V-AKT MURINE THYMOMA VTRAL ONCOGENE HOMOLOG I & $1.34 \pm 0.15$ & $1.44 \pm 0.05$ & $1.36 \pm 0.07$ \\
\hline AAI 27854 & INTEGRIN, ALPHA 5 (FIBRONECTIN RECEPTOR, ALPHA POLYPEPTIDE) & $1.4 \pm 0.08$ & $1.12 \pm 0.03$ & $1.22 \pm 0.06$ \\
\hline BG497332 & THROMBOSPONDIN I & $0.87 \pm 0.01$ & $1.1 \pm 0.1$ & $2.24 \pm 0.11$ \\
\hline R25275 & GLYCOGEN SYNTHASE KINASE 3 BETA. & $1.15 \pm 0.16$ & $1.36 \pm 0.04$ & $1.23 \pm 0.06$ \\
\hline BQ016959 & COLLAGEN, TYPE IV, ALPHA 2 & $1.18 \pm 0.07$ & $1.3 \pm 0$ & $1.33 \pm 0.09$ \\
\hline BM999610 & V-JUN SARCOMA VIRUS I7 ONCOGENE HOMOLOG (AVIAN) & $1.57 \pm 0.26$ & $2.13 \pm 0.01$ & $1.66 \pm 0.18$ \\
\hline AA044582 & INTEGRIN, BETA 8 & $0.33 \pm 0.03$ & $0.26 \pm 0.04$ & $0.25 \pm 0$ \\
\hline T75436 & MITOGEN-ACTIVATED PROTEIN KINASE 10 & $1.16 \pm 0.17$ & $1.22 \pm 0.05$ & $1.37 \pm 0.07$ \\
\hline AA069424 & INSULIN-LIKE GROWTH FACTOR I RECEPTOR & $1.5 \pm 0.09$ & $1.16 \pm 0.07$ & $1.02 \pm 0.05$ \\
\hline B1752921 & PLATELET-DERIVED GROWTH FACTOR RECEPTOR, BETA POLYPEPTIDE & $1.43 \pm 0.09$ & $1.03 \pm 0.02$ & $1.09 \pm 0.07$ \\
\hline N99223 & INTEGRIN, ALPHA 9 & $1.46 \pm 0.12$ & $1.08 \pm$ & $1.29 \pm 0.01$ \\
\hline BQ017489 & ACTININ, ALPHA I & $1.57 \pm 0.22$ & $1.24 \pm 0.1$ & $1.5 \pm 0.1$ \\
\hline AA0I0526 & GLUCOCORTICOID RECEPTOR DNA BINDING FACTOR I & $1.44 \pm 0.14$ & $1.03 \pm 0.04$ & $1.31 \pm 0$ \\
\hline RI4058 & PROTEIN KINASE C, BETA I & $1.54 \pm 0.06$ & $1.08 \pm 0.01$ & $1.15 \pm 0$ \\
\hline AA005247 & MET PROTO-ONCOGENE (HEPATOCYTE GROWTH FACTOR RECEPTOR) & $1.68 \pm 0.34$ & $1.3 \pm 0.03$ & $1.14 \pm 0.07$ \\
\hline AA043909 & PTK2 PROTEIN TYROSINE KINASE 2 & $0.52 \pm 0.11$ & $0.52 \pm 0.12$ & $0.34 \pm 0$ \\
\hline
\end{tabular}

For description see legend of table 5

mitogenic pathways mediated by growth factors. Also, it has been shown that serum stimulation leads to activation of MAP kinase pathways [54]. Our data demonstrates that the effect of TGF- $\beta$ is more pronounced in A549 cells as compared to HPL1D cells and one of the reasons for this could be due to constitutively active MAP kinase pathway in tumour cells. This is evident from our data that shows loss of TGF- $\beta$ regulation of many genes following MAP kinase pathway specific inhibitors in A549 cells. A549 cells harbour a mutation at the $12^{\text {th }}$ codon of K-ras protooncogene [55]. This mutation renders constitutive activation of RAS protein resulting in active MAP kinase pathway in these cells. In HPL1D cells, there is no report of any mutation in the RAS genes or constitutively active MAP kinase pathway. It is possible that this may be one of the major differences responsible for the differential regulation of genes by TGF- $\beta$ in these cell-lines. HPL1D cells are growth inhibited by TGF- $\beta$ [15]. The differential regulation of certain tumour suppressor genes (WT1, S100A2, TSSC1), cell cycle related genes (CDC34, CHEK1) and extracellular matrix genes (fibronectin, collagen IV and VIII) by TGF- $\beta$ in HPL1D cells (see additional file 3, Table S3) points to a growth regulatory activity of TGF- $\beta$ in these cells. On the other hand, as discussed previously, genes that are known to play pro-tumourigenic roles such as thrombospondin, integrins, transglutaminase, $\alpha 2$-macroglobulin etc. are regulated in A549 cells (see additional file 2, Table S2). Taken together, the differential regulation of genes in A549 and HPL1D cells could be due to pro-tumourigenic or growth inhibitory roles of TGF- $\beta$ on these cells.

\section{Conclusion}

In conclusion, by microarray and real time RT-PCR experiments, we show that 1 ] TGF- $\beta$ regulates more number of genes in transformed cells as compared to non-transformed cells; 2] evidence for differential regulation of gene expression in normal and tumour cells by TGF- $\beta$; and 3] that involvement of MAP kinase pathways may be one of the major mechanisms of TGF- $\beta$ actions. 
Table 9: TGF- $\beta$ regulated genes (26) in A549 involved in insulin signalling

\begin{tabular}{|c|c|c|c|c|}
\hline Acc No & DAVID Gene Name & I hr & $4 \mathrm{hr}$ & $12 \mathrm{hr}$ \\
\hline R23436 & PROTEIN KINASE, CAMP-DEPENDENT, REGULATORY, TYPE II, ALPHA & $0.32 \pm 0.03$ & $0.52 \pm 0.03$ & $0.22 \pm 0.01$ \\
\hline BI855956 & LIPASE, HORMONE-SENSITIVE & $1.17 \pm 0.06$ & $1.12 \pm 0.1$ & $1.38 \pm 0.07$ \\
\hline W32908 & FORKHEAD BOX OIA (RHABDOMYOSARCOMA) & $0.46 \pm 0.17$ & $0.38 \pm 0.01$ & $0.3 \pm 0.05$ \\
\hline R48236 & SUPPRESSOR OF CYTOKINE SIGNALING 3 & $1.02 \pm 0.21$ & $1.51 \pm 0$ & $1.45 \pm 0.09$ \\
\hline BF034I27 & INSULIN RECEPTOR SUBSTRATE 2 & $0.3 \pm 0.2$ & $0.2 \pm 0.09$ & $0.33 \pm 0.01$ \\
\hline BG502582 & CALMODULIN I (PHOSPHORYLASE KINASE, DELTA) & $0.89 \pm 0.02$ & $1.41 \pm 0.07$ & $1.21 \pm 0.14$ \\
\hline R74161 & PHOSPHORYLASE, GLYCOGEN; LIVER (HERS DISEASE, GLYCOGEN STORAGE DISEASE TYPE VI) & $0.23 \pm 0.06$ & $0.28 \pm 0.08$ & $0.28 \pm 0.02$ \\
\hline AA030048 & PROTEIN KINASE, CAMP-DEPENDENT, REGULATORY, TYPE I, BETA & $1.1 \pm 0.03$ & $1.02 \pm 0.06$ & $1.31 \pm 0.01$ \\
\hline BM556894 & RAPTOR & $0.89 \pm$ & $1.34 \pm 0.04$ & $1.29 \pm 0.19$ \\
\hline AV747676 & V-AKT MURINE THYMOMA VIRAL ONCOGENE HOMOLOG 3 (PROTEIN KINASE B, GAMMA) & $1.06 \pm 0.13$ & $1.46 \pm 0.05$ & $1.18 \pm 0.01$ \\
\hline AA127934 & PROTEIN KINASE, X-LINKED & $1.21 \pm 0.07$ & $1.38 \pm 0.01$ & $1.35 \pm 0.07$ \\
\hline H89206 & PROTEIN KINASE, CAMP-DEPENDENT, CATALYTIC, BETA & $1.18 \pm 0.08$ & $1.42 \pm 0.04$ & $1.25 \pm 0.03$ \\
\hline W35243 & PHOSPHOFRUCTOKINASE, PLATELET & $1.15 \pm 0.05$ & $1.39 \pm 0.06$ & $1.34 \pm 0.17$ \\
\hline T93745 & EUKARYOTIC TRANSLATION INITIATION FACTOR 4E MEMBER 2 & $1.4 \pm 0$ & $1.09 \pm 0.11$ & $1.06 \pm 0.03$ \\
\hline T39460 & PROTEIN PHOSPHATASE I, CATALYTIC SUBUNIT, ALPHA ISOFORM & $1.35 \pm 0.17$ & $1.38 \pm 0.04$ & $1.49 \pm 0.15$ \\
\hline H80740 & PHOSPHOFRUCTOKINASE, MUSCLE & $1.42 \pm 0.05$ & $1.25 \pm 0.04$ & $1.36 \pm 0.14$ \\
\hline AA056664 & V-AKT MURINE THYMOMA VIRAL ONCOGENE HOMOLOG I & $1.34 \pm 0.15$ & $1.44 \pm 0.05$ & $1.36 \pm 0.07$ \\
\hline H52478 & TUBEROUS SCLEROSIS 2 & $1.23 \pm 0.2$ & $1.32 \pm 0.05$ & $1.4 \pm 0.01$ \\
\hline R25275 & GLYCOGEN SYNTHASE KINASE 3 BETA & $1.15 \pm 0.16$ & $1.36 \pm 0.04$ & $1.23 \pm 0.06$ \\
\hline $\mathrm{H} 64260$ & PROTEIN KINASE, AMP-ACTIVATED, GAMMA 2 NON-CATALYTIC SUBUNIT & $1.69 \pm$ & $1.21 \pm$ & $1.46 \pm 0.05$ \\
\hline T75436 & MITOGEN-ACTIVATED PROTEIN KINASE IO & $1.16 \pm 0.17$ & $1.22 \pm 0.05$ & $1.37 \pm 0.07$ \\
\hline T75267 & FK506 BINDING PROTEIN I2-RAPAMYCIN ASSOCIATED PROTEIN I & $1.77 \pm 0.24$ & $1.37 \pm 0.05$ & $1.2 \pm 0.06$ \\
\hline H44888 & SUPPRESSOR OF CYTOKINE SIGNALING 6 & $0.25 \pm 0.13$ & $0.16 \pm$ & $0.18 \pm 0.01$ \\
\hline H59587 & ACETYL-COENZYME A CARBOXYLASE ALPHA & $1.42 \pm 0.44$ & $1.32 \pm 0.01$ & $1.18 \pm 0$ \\
\hline H08429 & TUBEROUS SCLEROSIS I & $1.43 \pm 0.09$ & $1.09 \pm 0.07$ & $1.35 \pm 0.1$ \\
\hline AA010882 & GLYCOGEN SYNTHASE I (MUSCLE) & $1.46 \pm 0.07$ & $1.15 \pm 0$ & $1.01 \pm 0.08$ \\
\hline
\end{tabular}

For description see legend of table 5

TGFBIP

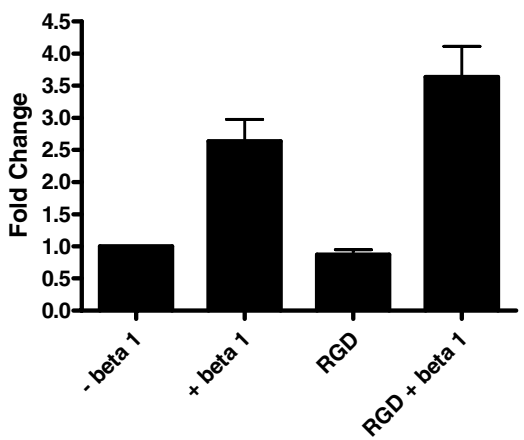

Integrin

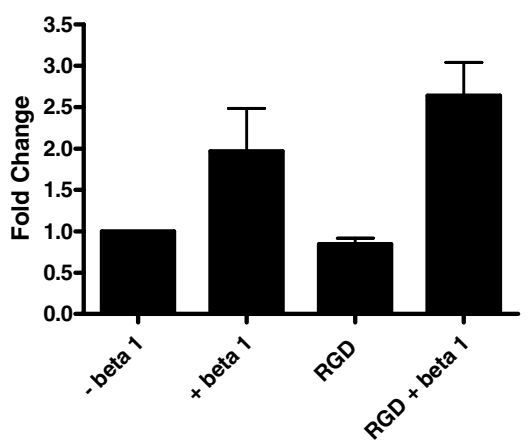

TMEPA

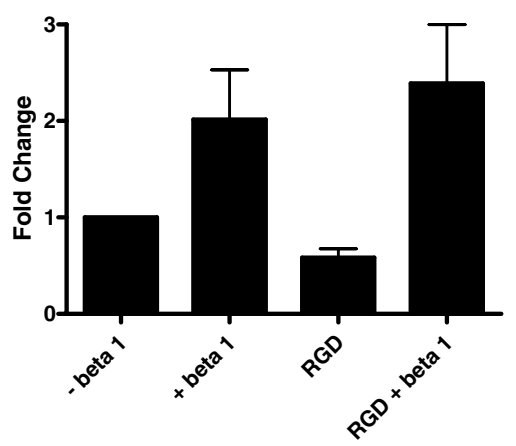

MMP2

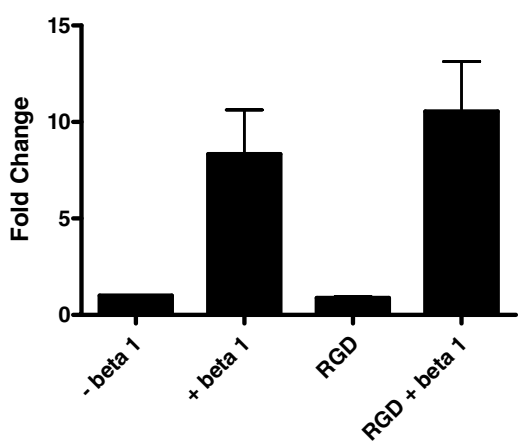

IGFBP7

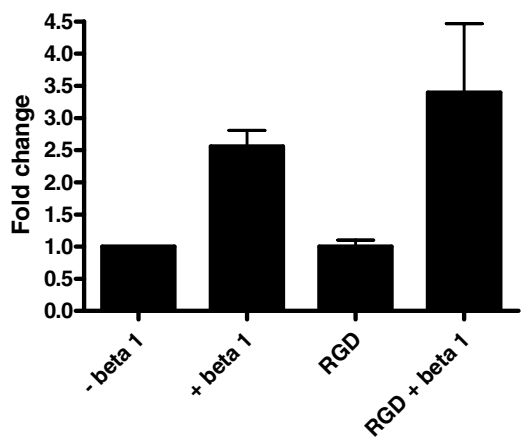

TSP1

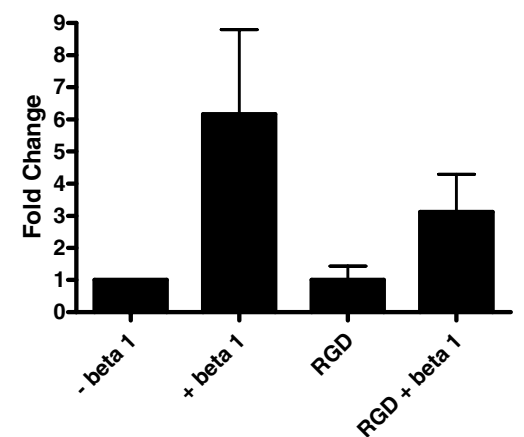

Figure 7

Effect of blocking the Integrin-linked signalling on the regulation of gene expression by TGF- $\beta$ in A549 cells. The cells were grown to $90 \%$ confluence, washed with serum free medium, treated with $500 \mu g / m l$ GRGDNP peptide 3 hours prior to treatment with TGF- $\beta$. The cells were harvested after 12 hours following TGF- $\beta$ treatment and processed for qRT$\mathrm{PCR}$ as described in Figure 3. 
Table 10: TGF- $\beta$ regulated genes (36) in A549 involved in regulation of actin cytoskeleton

\begin{tabular}{|c|c|c|c|c|}
\hline Acc No & DAVID Gene Name & I hr & $4 \mathrm{hr}$ & $12 \mathrm{hr}$ \\
\hline H83405 & FYVE, RHOGEF AND PH DOMAIN CONTAINING I (FACIOGENITAL DYSPLASIA) & $0.57 \pm 0.41$ & $0.35 \pm$ & $0.26 \pm 0.01$ \\
\hline N45505 & VAV I ONCOGENE & $0.64 \pm 0.37$ & $0.41 \pm 0.11$ & $0.31 \pm 0.01$ \\
\hline N455।8 & NCK-ASSOCIATED PROTEIN I & $1.03 \pm 0.12$ & $1.76 \pm 0.2$ & $1.39 \pm 0.18$ \\
\hline AA046597 & INTEGRIN, BETA 4 & $1.26 \pm 0.21$ & $1.1 \pm 0.19$ & $1.8 \pm 0.18$ \\
\hline R52046 & ACTININ, ALPHA 4 & $1.26 \pm 0.68$ & $1.21 \pm$ & $1.81 \pm 0.21$ \\
\hline N42722 & GUANINE NUCLEOTIDE BINDING PROTEIN (G PROTEIN), GAMMA I2 & $1.44 \pm 0.04$ & $1.5 \pm 0.09$ & $1.28 \pm 0.17$ \\
\hline AL598940 & MYOSIN, LIGHT POLYPEPTIDE I, ALKALI; SKELETAL, FAST & $1.15 \pm 0.01$ & $1.33 \pm 0.17$ & $1.56 \pm 0.02$ \\
\hline BE738680 & RAS HOMOLOG GENE FAMILY, MEMBER A & $1.24 \pm 0.11$ & $1.4 \pm 0.06$ & $1.51 \pm 0.03$ \\
\hline $\mathrm{H} 73472$ & CELL DIVISION CYCLE 42 (GTP BINDING PROTEIN, 25KDA) & $1.24 \pm 0.27$ & $1.33 \pm 0.07$ & $1.56 \pm 0.01$ \\
\hline WI7002 & INTEGRIN, ALPHA V (VITRONECTIN RECEPTOR, ALPHA POLYPEPTIDE, ANTIGEN CD5I) & $1.21 \pm 0.06$ & $2.32 \pm 0.29$ & $2.73 \pm 0.28$ \\
\hline AA088648 & FIBROBLAST GROWTH FACTOR RECEPTOR I (FMS-RELATED TYROSINE KINASE 2, PFEIFFER SYNDROME) & $1.45 \pm 0.24$ & $1.97 \pm 0.08$ & $1.77 \pm 0.09$ \\
\hline N57424 & T-CELL LYMPHOMA INVASION AND METASTASIS I & $1.35 \pm 0.02$ & $1.23 \pm 0.04$ & $1.34 \pm 0.02$ \\
\hline $\mathrm{HIO6I6}$ & PROFILIN 2 & $1.44 \pm 0.08$ & $1.49 \pm 0.11$ & $1.1 \pm 0$ \\
\hline BM9I2016 & P2I(CDKNIA)-ACTIVATED KINASE 4 & $1.29 \pm 0.03$ & $1.1 \pm 0.23$ & $1.54 \pm 0.03$ \\
\hline $\mathrm{H} 23109$ & FIBROBLAST GROWTH FACTOR I (ACIDIC) & $0.94 \pm$ & $1.36 \pm 0.01$ & $1.13 \pm 0.05$ \\
\hline BM924824 & RAS-RELATED C3 BOTULINUM TOXIN SUBSTRATE I (RHO FAMILY, SMALL GTP BINDING PROTEIN RACI) & $1.39 \pm 0$ & $1.41 \pm 0.06$ & $1.28 \pm 0.18$ \\
\hline HI5287 & P2I(CDKNIA)-ACTIVATED KINASE 6 & $1.47 \pm 0.08$ & $1.21 \pm 0.05$ & $1.57 \pm 0.04$ \\
\hline T39460 & PROTEIN PHOSPHATASE I, CATALYTIC SUBUNIT, ALPHA ISOFORM & $1.35 \pm 0.17$ & $1.38 \pm 0.04$ & $1.49 \pm 0.15$ \\
\hline BM888I57 & THYMOSIN, BETA 4, X-LINKED & $1.02 \pm$ & $1.58 \pm$ & $1.93 \pm 0.14$ \\
\hline T83।74 & ACTIN RELATED PROTEIN 2/3 COMPLEX, SUBUNIT IB, 4IKDA & $1.24 \pm 0.08$ & $1.06 \pm 0.1$ & $1.54 \pm 0.04$ \\
\hline AAI 27854 & INTEGRIN, ALPHA 5 (FIBRONECTIN RECEPTOR, ALPHA POLYPEPTIDE) & $1.4 \pm 0.08$ & $1.12 \pm 0.03$ & $1.22 \pm 0.06$ \\
\hline $\mathrm{H} 27657$ & G PROTEIN-COUPLED RECEPTOR KINASE INTERACTOR I & $1.39 \pm 0.09$ & $1.11 \pm 0.04$ & $1.34 \pm 0.25$ \\
\hline N29131 & MOESIN & $1.37 \pm 0.09$ & $1.03 \pm 0.06$ & $1.42 \pm 0.05$ \\
\hline AA044582 & INTEGRIN, BETA 8 & $0.33 \pm 0.03$ & $0.26 \pm 0.04$ & $0.25 \pm 0$ \\
\hline T77476 & GUANINE NUCLEOTIDE BINDING PROTEIN (G PROTEIN), ALPHA I3 & $1.39 \pm 0.41$ & $1.59 \pm 0.08$ & $1.24 \pm 0.14$ \\
\hline R35I67 & BAII-ASSOCIATED PROTEIN 2 & $1.46 \pm 0.15$ & $0.97 \pm 0.02$ & $1.32 \pm 0.12$ \\
\hline H06909 & PROTEIN PHOSPHATASE I, REGULATORY (INHIBITOR) SUBUNIT I2B & $1.34 \pm 0.03$ & $1.16 \pm 0.01$ & $1.08 \pm 0.03$ \\
\hline $\mathrm{H} 14999$ & RAC/CDC42 GUANINE NUCLEOTIDE EXCHANGE FACTOR (GEF) 6 & $0.22 \pm 0.13$ & $0.27 \pm 0.14$ & $0.28 \pm 0$ \\
\hline N77II 2 & IQ MOTIF CONTAINING GTPASE ACTIVATING PROTEIN I & $1.6 \pm 0.35$ & $1.54 \pm 0.13$ & $1.48 \pm 0.04$ \\
\hline BI75292I & PLATELET-DERIVED GROWTH FACTOR RECEPTOR, BETA POLYPEPTIDE & $1.43 \pm 0.09$ & $1.03 \pm 0.02$ & $1.09 \pm 0.07$ \\
\hline N99223 & INTEGRIN, ALPHA 9 & $1.46 \pm 0.12$ & $1.08 \pm$ & $1.29 \pm 0.01$ \\
\hline $\mathrm{BI} 258438$ & COFILIN I (NON-MUSCLE) & $1.24 \pm 0.09$ & $1.08 \pm 0.09$ & $1.42 \pm 0.04$ \\
\hline BQ0I7489 & ACTININ, ALPHA I & $1.57 \pm 0.22$ & $1.24 \pm 0.1$ & $1.5 \pm 0.1$ \\
\hline $\mathrm{H} 5 \mathrm{I} 445$ & LIM DOMAIN KINASE I & $1.3 \pm 0$ & $1.02 \pm 0.11$ & $1.12 \pm 0.01$ \\
\hline AA0I0526 & GLUCOCORTICOID RECEPTOR DNA BINDING FACTOR I & $1.44 \pm 0.14$ & $1.03 \pm 0.04$ & $1.31 \pm 0$ \\
\hline AA043909 & PTK2 PROTEIN TYROSINE KINASE 2 & $0.52 \pm 0.11$ & $0.52 \pm 0.12$ & $0.34 \pm 0$ \\
\hline
\end{tabular}

For description see legend of table 5

\section{Methods}

\section{Cell-lines and cultures}

A549, a lung adenocarcinoma cell-line was cultured in DMEM (Sigma-Aldrich, USA) with 10\% foetal bovine serum (FBS), 100 units $/ \mathrm{ml}$ penicillin and $100 \mu \mathrm{g} / \mathrm{ml}$ streptomycin, $2.5 \mu \mathrm{g} / \mathrm{ml}$ fungizone (Invitrogen Life Sciences, USA). HPL1D, an immortalized lung epithelial cell-line was cultured in Ham's F-12 supplemented with 5\% FBS, 5 $\mu \mathrm{g} / \mathrm{ml}$ bovine insulin, $5 \mu \mathrm{g} / \mathrm{ml}$ human transferrin, $10^{-7} \mathrm{M}$ hydrocortisone, $2 \times 10^{-10} \mathrm{M}$ tri-iodo thyronine and $20 \mathrm{ng} /$ $\mathrm{ml}$ EGF [15]. All the cell-lines were maintained at $37^{\circ} \mathrm{C}$ in a humid atmosphere with $5 \% \mathrm{CO}_{2}$.

\section{Treatments}

The cell-lines were grown to $90 \%$ confluence in the respective growth media followed by serum free washes $(3$ times) for 24 hours and then treated with $5 \mathrm{ng} / \mathrm{ml}$ TGF- $\beta 1$ (R\&D systems, USA) for different intervals of time. For signal transduction pathway inhibitor experiments, cells were pre-treated with $10 \mu \mathrm{M}$ SB203580 (p38 inhibitor), $10 \mu \mathrm{M}$ PD98050 (ERK inhibitor), and $10 \mu \mathrm{M}$ JNK inhibi- tor I (L-form) (all from Calbiochem) for 1 hour, and 500 $\mu \mathrm{g} / \mathrm{ml}$ GRGDNP peptide (custom synthesized) for 2-3 hours prior to TGF- $\beta$ treatments.

\section{RNA isolation, cDNA labelling and microarray analysis}

Total RNA was isolated from cells using TRI reagent (Sigma-Aldrich, USA) according to manufacturer's protocol. The RNA was re-precipitated with $0.3 \mathrm{M}$ sodium acetate ( $\mathrm{pH}$ 5.2) and ethanol, further purified using RNAeasy columns (Qiagen, GmbH, Germany). The RNA quantity and quality were assessed by $\mathrm{OD}_{260}$ and $\mathrm{OD}_{280}$ measurements on a spectrophotometer and the integrity was determined by MOPS-formaldehyde gel. The labelling of the cDNA for microarray was done using Micromax Direct Labelling kit (Perkin Elmer Life Sciences Inc. USA) according to manufacturer's instructions. For each labelling reaction, $20 \mu \mathrm{g}$ of total RNA was used. The control RNA was labelled with Cy3-dUTP and the TGF- $\beta 1$ treated RNA with Cy5-dUTP. Both the labelled products were mixed and precipitated with $0.3 \mathrm{M}$ sodium acetate $(\mathrm{pH} 5.2)$ and ethanol. A small quantity of the precipitated labelled 
Table I I: TGF- $\beta$ regulated genes (23) in A549 involved in Wnt signalling

\begin{tabular}{|c|c|c|c|c|}
\hline Acc No & DAVID Gene Name & I hr & $4 \mathrm{hr}$ & $12 \mathrm{hr}$ \\
\hline H78804 & SMAD, MOTHERS AGAINST DPP HOMOLOG 3 (DROSOPHILA) & $1.22 \pm 0.09$ & $1.36 \pm 0.02$ & $1.15 \pm 0.06$ \\
\hline AA029506 & CALCIUM/CALMODULIN-DEPENDENT PROTEIN KINASE (CAM KINASE) II DELTA & $1.29 \pm 0.22$ & $1.41 \pm 0.07$ & $1.44 \pm 0.02$ \\
\hline AA027986 & PROTEIN PHOSPHATASE 2 (FORMERLY 2A), CATALYTIC SUBUNIT, ALPHA ISOFORM & $1.24 \pm 0.15$ & $1.65 \pm 0.03$ & $1.34 \pm 0.11$ \\
\hline AA029516 & TRANSCRIPTION FACTOR 7-LIKE 2 (T-CELL SPECIFIC, HMG-BOX) & $1.25 \pm 0.02$ & $1.41 \pm 0.02$ & $1.14 \pm 0.2$ \\
\hline AA044665 & F-BOX AND WD-40 DOMAIN PROTEIN II & $1.09 \pm 0.02$ & $1.31 \pm 0.02$ & $1.07 \pm 0.1$ \\
\hline AA030029 & PROTEIN KINASE C, ALPHA & $1.33 \pm 0.23$ & $1.56 \pm 0.08$ & $1.36 \pm 0.03$ \\
\hline BE738680 & RAS HOMOLOG GENE FAMILY, MEMBER A & $1.24 \pm 0.11$ & $1.4 \pm 0.06$ & $1.51 \pm 0.03$ \\
\hline R55I34 & TRANSCRIPTION FACTOR 7-LIKE I (T-CELL SPECIFIC, HMG-BOX) & $1.45 \pm 0.03$ & $1.2 \pm 0.1$ & $1.27 \pm 0.05$ \\
\hline W49562 & PHOSPHOLIPASE C, BETA 4 & $1.26 \pm 0.25$ & $1.27 \pm 0.04$ & $1.77 \pm 0.27$ \\
\hline AAI 27934 & PROTEIN KINASE, X-LINKED & $1.21 \pm 0.07$ & $1.38 \pm 0.01$ & $1.35 \pm 0.07$ \\
\hline H89206 & PROTEIN KINASE, CAMP-DEPENDENT, CATALYTIC, BETA & $1.18 \pm 0.08$ & $1.42 \pm 0.04$ & $1.25 \pm 0.03$ \\
\hline N72642 & CALCYCLIN BINDING PROTEIN & $1.38 \pm 0.01$ & $1.5 \pm 0.12$ & $1.08 \pm 0.06$ \\
\hline BM924824 & RAS-RELATED C3 BOTULINUM TOXIN SUBSTRATE I (RHO FAMILY, SMALL GTP BINDING PROTEIN RACI) & $1.39 \pm 0$ & $1.41 \pm 0.06$ & $1.28 \pm 0.18$ \\
\hline W518II & WINGLESS-TYPE MMTV INTEGRATION SITE FAMILY, MEMBER 5A & $1.48 \pm 0.1$ & $1.54 \pm 0.06$ & $1.51 \pm 0.19$ \\
\hline BM31।217 & WINGLESS-TYPE MMTV INTEGRATION SITE FAMILY, MEMBER 4 & $1.63 \pm$ & $0.97 \pm$ & $1.5 \pm 0.02$ \\
\hline R25275 & GLYCOGEN SYNTHASE KINASE 3 BETA & $1.15 \pm 0.16$ & $1.36 \pm 0.04$ & $1.23 \pm 0.06$ \\
\hline AAI52025 & FRIZZLED HOMOLOG 4 (DROSOPHILA) & $1.47 \pm 0.28$ & $1.56 \pm 0.14$ & $1.27 \pm 0.12$ \\
\hline BM999610 & V-JUN SARCOMA VIRUS I7 ONCOGENE HOMOLOG (AVIAN) & $1.57 \pm 0.26$ & $2.13 \pm 0.01$ & $1.66 \pm 0.18$ \\
\hline T75436 & MITOGEN-ACTIVATED PROTEIN KINASE 10 & $1.16 \pm 0.17$ & $1.22 \pm 0.05$ & $1.37 \pm 0.07$ \\
\hline AA028175 & CULLIN I & $1.51 \pm 0.15$ & $1.15 \pm 0.04$ & $0.96 \pm 0.02$ \\
\hline H70045 & CALCIUM/CALMODULIN-DEPENDENT PROTEIN KINASE (CAM KINASE) II GAMMA & $1.45 \pm 0.08$ & $1.39 \pm 0.16$ & $1.21 \pm 0.12$ \\
\hline$R 72188$ & LOW DENSITY LIPOPROTEIN RECEPTOR-RELATED PROTEIN 5 & $1.27 \pm 0.13$ & $0.87 \pm$ & $1.38 \pm 0.02$ \\
\hline RI4058 & PROTEIN KINASE C, BETA I & $1.54 \pm 0.06$ & $1.08 \pm 0.01$ & $1.15 \pm 0$ \\
\hline
\end{tabular}

For description see legend of table 5

TGFBIP

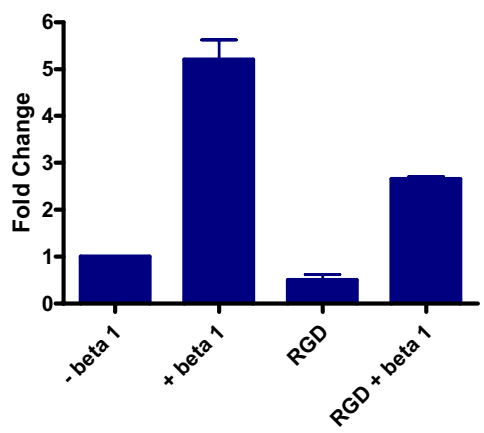

Integrin

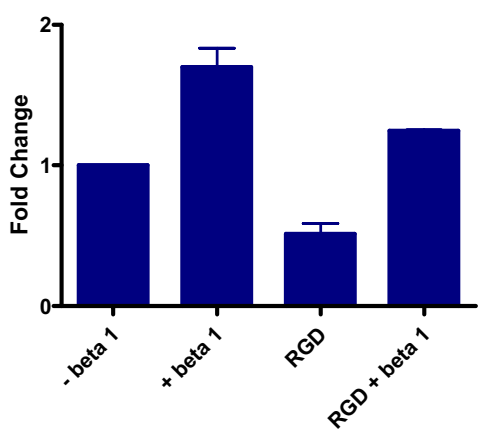

TMEPA

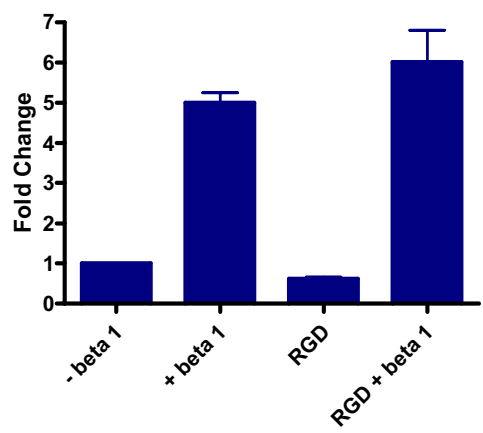

MMP2

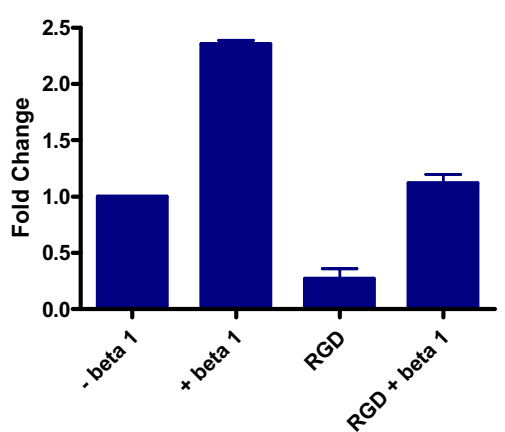

IGFBP7

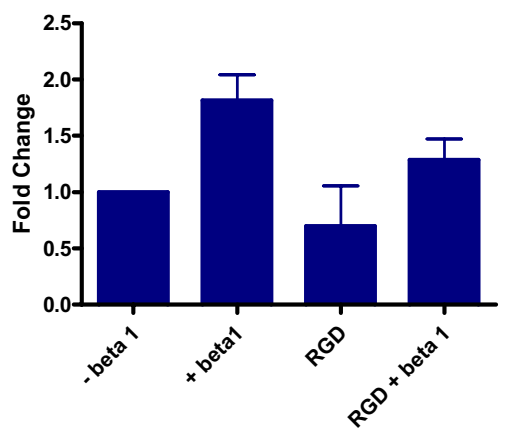

TSP 1

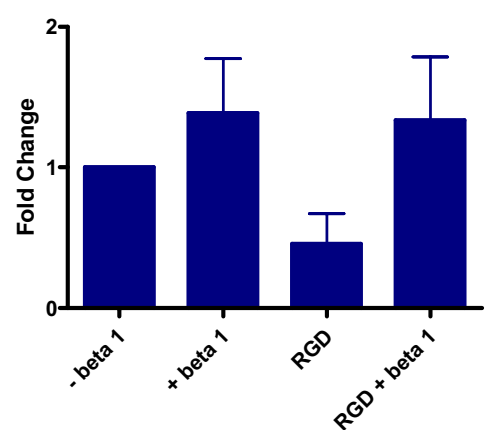

Figure 8

Effect of blocking the Integrin-linked signalling on the regulation of gene expression by TGF- $\beta$ in HPLID cells. The cells were grown to $90 \%$ confluence, washed with serum free medium, treated with $500 \mu \mathrm{g} / \mathrm{ml}$ GRGDNP peptide 3 hours prior to treatment with TGF- $\beta$. The cells were harvested after 12 hours following TGF- $\beta$ treatment and processed for qRT$\mathrm{PCR}$ as described in Figure 3. 
cDNA was assessed for labelling efficiency on a 1\% agarose gel and scanned using the Typhoon 9210 scanner (GE Life Sciences). $160 \mu$ l of hybridisation buffer (Ultrahyb, Sigma-Aldrich, USA) was added to the probe, incubated at $75^{\circ} \mathrm{C}$ for 5 minutes and then added to the human $19 \mathrm{~K}$ array (University Health network, Toronto). The hybridisation was carried out in the GeneTAC Hyb Station (Genomic Solutions, UK) at $65^{\circ}$ for 4 hours, $60^{\circ}$ for 4 hours and $55^{\circ}$ for 10 hours. The slides were then washed with medium stringency $(2 \times$ SSC and $0.1 \%$ SDS $)$, high stringency $(0.1 \times$ SSC and $0.1 \%$ SDS $)$ and post wash $(0.1 \times$ SSC) buffers for 5 minutes each, dried and scanned using a scanner (Scanarray Express, Perkin Elmer Life Sciences, USA).

\section{Microarray image and data analyses}

All the image analyses have been done using the Quantarray software (Perkin Elmer Life Sciences, USA). Filtering and compilation of data have been done using Microsoft Excel and Microsoft Access. Spots of compromised quality and with low intensity were eliminated from the analysis. The data was normalized by LOWESS method (Avadis 3.1, Strand Life Sciences, India), Сy5:Cy3 ratios were established and $\log _{2}$ values were calculated. Hybridizations of RNA from each time point were performed on duplicate (technical duplicate) arrays and only those genes, which showed consistent regulation, have been considered for analysis. Genes which show $\log _{2}$ ratios greater than 0.37 ( 1.3 fold induced) or less than -1.5 (3 fold down regulated) in the duplicate arrays at any one of the time points have been considered as regulated by TGF$\beta$. The cut-off values for regulated genes were decided based on our observation of the data where genes that were known to be up regulated by TGF- $\beta$ were showing > 1.3 and $<0.33$ fold difference in the microarray.

\section{Real Time PCR analyses}

For cDNA synthesis, two micrograms of total RNA was reverse transcribed using the $\mathrm{ABI}$ CDNA Archive kit (Applied Biosystems, USA). Complementary DNA (cDNA) equivalent to $10 \mathrm{ng}$ of total RNA was used for all the PCR reactions. The sequences of the primers are shown in Table 1 . All the PCR reactions have been done using Dynamo SYBR green mix (Finnzymes, Finland) in ABI Prism 7900HT sequence detection system (Applied Biosystems, USA). The analysis has been done using SDS 2.1 software (Applied Biosystems, USA). For normalization of RT-PCR data, RPL35a expression (which was previously found to be unchanged in microarray experiments) was used and fold over control at each of the time point has been calculated as follows

$$
\begin{aligned}
& \delta \mathrm{CT}=\mathrm{CT}_{\text {gene }^{-}-\mathrm{CT}_{\mathrm{RPL}}} \\
& \delta \delta \mathrm{CT}=\delta \mathrm{CT}_{\text {treated }} \delta \mathrm{CT}_{\text {untreated }}
\end{aligned}
$$

Fold Change $=2^{-\delta \delta C T}$.

\section{Authors' contributions}

PR designed and executed the experiments, interpreted the data and prepared the manuscript; AA, RB and RKRK analysed the microarray data and prepared the gene lists and figures; AC performed the real time PCR experiments and analysis of data; TT provided the support in the design of experiments and PK conceived the study, participated in its design and coordination and helped to draft the manuscript. All authors read and approved the final manuscript.

\section{Additional material}

\section{Additional file 1}

List of genes commonly regulated by TGF- $\beta$ in HPL1D and A549 celllines. A list of genes, which are regulated by TGF- $\beta$ in both HPL1D and A549 cell-lines along with the fold changes at 1, 4 and 12 hrs of treatment.

Click here for file

[http://www.biomedcentral.com/content/supplementary/14712164-8-98-S1.xls]

\section{Additional file 2}

List of genes regulated by TGF- $\beta$ in only A549 cell-line. A list of genes, which are regulated by TGF- $\beta$ in $A 549$ alone along with the fold changes at 1, 4 and 12 hrs of treatment.

Click here for file

[http://www.biomedcentral.com/content/supplementary/14712164-8-98-S2.xls]

\section{Additional file 3}

List of genes regulated by TGF- $\beta$ only in HPL1D cell-line. A list of genes, which are regulated by TGF- $\beta$ in HPL1D cell-line alone along with the fold changes at 1, 4 and 12 hrs of treatment.

Click here for file

[http://www.biomedcentral.com/content/supplementary/14712164-8-98-S3.xls] 


\section{Additional file 4}

Semi-quantitative RT-PCR analyses of selected genes with respect to regulation by TGF- $\beta$ in A549 and HPL1D cells. The respective cell-lines were grown to $90 \%$ confluence (as described in methods section), washed with serum free medium, treated with $5 \mathrm{ng} / \mathrm{ml}$ TGF- $\beta 1$ for $1,4,6,12$ and 24 hours. Each treatment also has untreated cells as control at each timepoint. Two microgram of total RNA from each treatment was reverse transcribed and cDNA equivalent to $20 \mathrm{ng}$ total RNA was used for the PCR reactions. All PCR reactions were done under non saturating conditions. The products were resolved on $2 \%$ agarose gel and the gel pictures were taken on Kodak Image station 440CF. The band intensities were quantified using Kodak 1D 3.6 software. A, ethidium bromide staining pattern of the PCR products. $B$ and $C$ graphs representing the fold change over untreated controls after normalization with the expression of RPL35a, in HPL1D and A549 cells respectively.

Click here for file

[http://www.biomedcentral.com/content/supplementary/14712164-8-98-S4.ppt]

\section{Additional file 5}

Induction of pSBE-Luc activity by TGF- $\beta$ in A549 cells. For SBE-luc induction by TGF- $\beta$ in A549 cells, twenty five thousand cells were plated in 24 well dishes 16-24 hours prior to transfection. $200 \mathrm{ng}$ of pSBE-luc plasmid and $1.25 \mathrm{ng}$ of $p R L-C M V$ construct (Renilla luciferase, for transfection normalization) were transfected using Effectene reagent (Qiagen $\mathrm{GmbH}$, Germany) in serum free conditions for $12 \mathrm{hrs}$. The cells were recovered in medium containing $10 \%$ FBS for 24 hours, washed with serum free medium for 24 hours ( 3 changes) and then treated with $5 \mathrm{ng} /$ $\mathrm{ml}$ TGF- $\beta$ for 18 hours. The cells were then lysed and lysates were used for dual-luciferase assay (Promega inc, USA). The ratio of the firefly-luci-

ferase to renilla-luciferase has been plotted on the $y$-axis.

Click here for file

[http://www.biomedcentral.com/content/supplementary/14712164-8-98-S5.ppt] 


\section{Acknowledgements}

We thank Dr. Karunagaran and Dr Bert Vogelstein for PSBE4-BV/Luc construct. We acknowledge the help of Dr. Gayathri Ramakrishnan and Praveen Arany for useful discussions, T.N. Vivek for the help with inhibitor experiments and P. Sreekanth Reddy for the help with Microarray and real time PCR experiments. We thank Dr. Ramesh Hariharan, Strand Life Sciences, Bangalore for Avadis microarray analysis software and M/s Unichem Laboratories, IISc for the GRGDNP peptide. Indian Council of Medical Research, India, funded this study. The infrastructural support received from University Grants Commission and Department of Science and Technology (DST FIST), Govt. of India, New Delhi is acknowledged.

\section{References}

I. Kulkarni $A B$, Thyagarajan $T$, Letterio JJ: Function of cytokines within the TGF-beta superfamily as determined from transgenic and gene knockout studies in mice. Curr Mol Med 2002, 2(3):303-327.

2. Levy L, Hill CS: Alterations in components of the TGF-beta superfamily signaling pathways in human cancer. Cytokine Growth Factor Rev 2006, I 7( I-2):4I-58.

3. Roberts $A B$, Wakefield $L M$ : The two faces of transforming growth factor beta in carcinogenesis. Proc Natl Acad Sci U S A 2003, I 00( I 5):862I-8623.

4. Engle SJ, Hoying JB, Boivin GP, Ormsby I, Gartside PS, Doetschman T: Transforming growth factor betal suppresses nonmetastatic colon cancer at an early stage of tumorigenesis. Cancer Res 1999, 59( I 4):3379-3386.

5. Siegel PM, Shu W, Cardiff RD, Muller WJ, Massague J: Transforming growth factor beta signaling impairs Neu-induced mammary tumorigenesis while promoting pulmonary metastasis. Proc Natl Acad Sci U S A 2003, I 00( I 4):8430-8435.

6. Pardali K, Moustakas A: Actions of TGF-beta as tumor suppressor and pro-metastatic factor in human cancer. Biochim Biophys Acta 2006.

7. Muraoka-Cook RS, Dumont N, Arteaga CL: Dual role of transforming growth factor beta in mammary tumorigenesis and metastatic progression. Clin Cancer Res 2005, II (2 Pt 2):937s-43s.

8. Yang YA, Dukhanina O, Tang B, Mamura M, Letterio JJ, MacGregor J, Patel SC, Khozin S, Liu ZY, Green J, Anver MR, Merlino G, Wakefield LM: Lifetime exposure to a soluble TGF-beta antagonist protects mice against metastasis without adverse side effects. J Clin Invest 2002, 109(12):1607-1615.

9. Muraoka RS, Dumont N, Ritter CA, Dugger TC, Brantley DM, Chen J, Easterly E, Roebuck LR, Ryan S, Gotwals PJ, Koteliansky V, Arteaga CL: Blockade of TGF-\{beta\} inhibits mammary tumor cell viability, migration, and metastases. J Clin Invest 2002, 109(I 2):155I-1559.

10. Ao M, Williams K, Bhowmick NA, Hayward SW: Transforming Growth Factor-\{beta\} Promotes Invasion in Tumorigenic but not in Nontumorigenic Human Prostatic Epithelial Cells. Cancer Res 2006, 66(16):8007-8016.

II. Lund LR, Romer J, Ronne E, Ellis V, Blasi F, Dano K: Urokinasereceptor biosynthesis, mRNA level and gene transcription are increased by transforming growth factor beta $I$ in human A549 lung carcinoma cells. Embo J 1991, I O(II):3399-3407.

12. Keski-Oja J, Blasi F, Leof EB, Moses HL: Regulation of the synthesis and activity of urokinase plasminogen activator in A549 human lung carcinoma cells by transforming growth factorbeta. J Cell Biol 1988, I06(2):45I-459.

13. Keski-Oja J, Raghow R, Sawdey M, Loskutoff DJ, Postlethwaite $A E$, Kang $\mathrm{AH}$, Moses HL: Regulation of mRNAs for type-I plasminogen activator inhibitor, fibronectin, and type I procollagen by transforming growth factor-beta. Divergent responses in lung fibroblasts and carcinoma cells. J Biol Chem 1988, 263(7):3|||-3||5.

14. Samuel SK, Hurta RA, Kondaiah P, Khalil N, Turley EA, Wright JA, Greenberg $\mathrm{AH}$ : Autocrine induction of tumor protease production and invasion by a metallothionein-regulated TGFbeta I (Ser223, 225). Embo J 1992, I I(4): 1599-1605.

15. Masuda A, Kondo M, Saito T, Yatabe Y, Kobayashi T, Okamoto M, Suyama M, Takahashi T, Takahashi T: Establishment of human peripheral lung epithelial cell lines (HPLI) retaining differentiated characteristics and responsiveness to epidermal growth factor, hepatocyte growth factor, and transforming growth factor beta I. Cancer Res 1997, 57(2I):4898-4904.

16. Kim SJ, Jeang KT, Glick AB, Sporn MB, Roberts AB: Promoter sequences of the human transforming growth factor-beta I gene responsive to transforming growth factor-beta I autoinduction. J Biol Chem 1989, 264(I 2):704I-7045.

17. Dennis G, Sherman B, Hosack D, Yang J, Gao W, Lane HC, Lempicki R: DAVID: Database for Annotation, Visualization, and Integrated Discovery. Genome Biology 2003, 4(5): P3.

18. Hocevar BA, Brown TL, Howe PH: TGF-beta induces fibronectin synthesis through a c-Jun $\mathbf{N}$-terminal kinase-dependent, Smad4-independent pathway. Embo J 1999, I 8(5): I345-1356.

19. Jonson T, Heidenblad M, Hakansson P, Gorunova L, Johansson B, Fioretos T, Hoglund M: Pancreatic carcinoma cell lines with SMAD4 inactivation show distinct expression responses to TGFB I. Genes Chromosomes Cancer 2003, 36(4):340-352.

20. Levy L, Hill CS: Smad4 dependency defines two classes of transforming growth factor \{beta\} (TGF-\{beta\}) target genes and distinguishes TGF-\{beta\}-induced epithelial-mesenchymal transition from its antiproliferative and migratory responses. Mol Cell Biol 2005, 25( I 8):8I 08-8I 25.

21. Scaffidi AK, Petrovic N, Moodley YP, Fogel-Petrovic M, Kroeger KM, Seeber RM, Eidne KA, Thompson PJ, Knight DA: alpha(v)beta(3) Integrin interacts with the transforming growth factor beta (TGFbeta) type II receptor to potentiate the proliferative effects of TGFbetal in living human lung fibroblasts. J Biol Chem 2004, 279(36):37726-37733.

22. Bhowmick NA, Zent R, Ghiassi M, McDonnell M, Moses HL: Integrin beta I signaling is necessary for transforming growth factorbeta activation of p38MAPK and epithelial plasticity. J Biol Chem 200I, 276(50):46707-467I3.

23. Xie L, Law BK, Aakre ME, Edgerton M, Shyr Y, Bhowmick NA, Moses $\mathrm{HL}$ : Transforming growth factor beta-regulated gene expression in a mouse mammary gland epithelial cell line. Breast Cancer Res 2003, 5(6):RI87-98.

24. Zavadil J, Bitzer M, Liang D, Yang YC, Massimi A, Kneitz S, Piek E, Bottinger EP: Genetic programs of epithelial cell plasticity directed by transforming growth factor-beta. Proc Natl Acad Sci U S A 200I, 98( I 2):6686-669I.

25. Renzoni E, Abraham D, Howat S, Shi-Wen X, Sestini P, Bou-Gharios G, Wells A, Veeraraghavan S, Nicholson A, Denton C, Leask A, Pearson J, Black C, Welsh K, du Bois R: Gene expression profiling reveals novel TGFbeta targets in adult lung fibroblasts. Respiratory Research 2004, 5(I):24.

26. Keating D, Sadlier D, Patricelli A, Smith S, Walls D, Egan J, Doran P: Microarray identifies ADAM family members as key responders to TGF-betal in alveolar epithelial cells. Respiratory Research 2006, 7(1): I14.

27. Kloth JN, Fleuren GJ, Oosting J, de Menezes RX, Eilers PH, Kenter GG, Gorter A: Substantial changes in gene expression of Wnt, MAPK and TNFalpha pathways induced by TGF-betal in cervical cancer cell lines. Carcinogenesis 2005, 26(9): | |493-I 502.

28. Hayashida-Hibino $S$, Watanabe $H$, Nishida $K$, Tsujikawa M, Tanaka T, Hori Y, Saishin Y, Tano Y: The Effect of TGF-\{beta\} I on Differential Gene Expression Profiles in Human Corneal Epithelium Studied by cDNA Expression Array. Invest Ophthalmol Vis Sci 200I, 42(8): I69I-1697.

29. Cao Y, Chen L, Zhang W, Liu Y, Papaconstantinou HT, Bush CR, Townsend JCM, Thompson EA, Ko TC: IDENTIFICATION OF APOPTOTIC GENES MEDIATING TRANSFORMING GROWTH FACTOR (TGF)-\{beta\}/Smad3-INDUCED CELL DEATH IN INTESTINAL EPITHELIAL CELLS USING A GENOMIC APPROACH. Am J Physiol Gastrointest Liver Physiol 2006:437.2005

30. Verrecchia F, Chu ML, Mauviel A: Identification of novel TGFbeta /Smad gene targets in dermal fibroblasts using a combined cDNA microarray/promoter transactivation approach. J Biol Chem 200I, 276(20): 17058-I7062.

31. Takayama S, Ishii S, Ikeda T, Masamura S, Doi M, Kitajima M: The relationship between bone metastasis from human breast cancer and integrin alpha(v)beta3 expression. Anticancer Res 2005, 25(IA):79-83.

32. Wang TN, Qian X, Granick MS, Solomon MP, Rothman VL, Berger DH, Tuszynski GP: Thrombospondin-I (TSP-I) Promotes the 
Invasive Properties of Human Breast Cancer. Journal of Surgical Research 1996, 63(1):39.

33. Harthun NL, Weaver AM, Brinckerhoff LH, Deacon DH, Gonias SL, Slingluff $C L$ Jr.: Activated alpha 2-macroglobulin reverses the immunosuppressive activity in human breast cancer cellconditioned medium by selectively neutralizing transforming growth factor-beta in the presence of interleukin-2. J Immunother 1998, 2 I(2):85-94.

34. Yue J, Mulder KM: Requirement of Ras/MAPK Pathway Activation by Transforming Growth Factor beta for Transforming Growth Factor beta I Production in a Smad-dependent Pathway. J Biol Chem 2000, 275(40):30765-30773.

35. Zhang $Y$, Feng $X H$, Derynck R: Smad3 and Smad4 cooperate with c-Jun/c-Fos to mediate TGF-[beta]-induced transcription. Nature 1998, 394(6696):909.

36. Piek E, Ju WJ, Heyer J, Escalante-Alcalde D, Stewart CL, Weinstein M, Deng C, Kucherlapati R, Bottinger EP, Roberts AB: Functional characterization of transforming growth factor beta signaling in Smad2- and Smad3-deficient fibroblasts. J Biol Chem 200I, 276(23): 19945-19953.

37. Moustakas A, Heldin CH: Non-Smad TGF-beta signals. J Cell Sci 2005, I I 8(Pt I6):3573-3584.

38. Nakagawa T, Lan HY, Glushakova O, Zhu HJ, Kang DH, Schreiner GF, Bottinger EP, Johnson RJ, Sautin YY: Role of ERKI/2 and p38 mitogen-activated protein kinases in the regulation of thrombospondin-I by TGF-betal in rat proximal tubular cells and mouse fibroblasts. J Am Soc Nephrol 2005, I 6(4):899-904.

39. Kim ES, Kim MS, Moon A: TGF-beta-induced upregulation of MMP-2 and MMP-9 depends on P38 MAPK, but not ERK signaling in MCFIOA human breast epithelial cells. Int J Oncol 2004, 25(5): I375-I 382.

40. Maliekal TT, Anto RJ, Karunagaran D: Differential activation of Smads in HeLa and $\mathrm{SiHa}$ cells that differ in their response to transforming growth factor-beta. I Biol Chem 2004, 279(35):36287-36292.

41. Derynck R, Zhang YE: Smad-dependent and Smad-independent pathways in TGF-beta family signalling. Nature 2003, 425(6958):577-584.

42. Massague J: How cells read TGF-beta signals. Nat Rev Mol Cell Biol 2000, I (3): 169-178.

43. Yakymovych I, Ten Dijke P, Heldin CH, Souchelnytskyi S: Regulation of Smad signaling by protein kinase C. Faseb J 200I, I 5(3):553-555.

44. Asano $\mathrm{Y}, \mathrm{lhn} \mathrm{H}$, Jinnin M, Mimura $\mathrm{Y}$, Tamaki K: Involvement of alphavbeta5 integrin in the establishment of autocrine TGFbeta signaling in dermal fibroblasts derived from localized scleroderma. J Invest Dermatol 2006, I 26(8): I76I-I769.

45. Asano Y, Ihn H, Yamane K, Jinnin M, Mimura Y, Tamaki K: Increased expression of integrin alpha(v)beta3 contributes to the establishment of autocrine TGF-beta signaling in scleroderma fibroblasts. J Immunol 2005, I 75( I I):7708-77/8.

46. Fjellbirkeland L, Cambier S, Broaddus VC, Hill A, Brunetta P, Dolganov G, Jablons D, Nishimura SL: Integrin alphavbeta8-mediated activation of transforming growth factor-beta inhibits human airway epithelial proliferation in intact bronchial tissue. Am J Pathol 2003, 163(2):533-542.

47. Campbell SL, Khosravi-Far R, Rossman KL, Clark GJ, Der CJ: Increasing complexity of Ras signaling. Oncogene I998, I7(I I Reviews): | 395-| 4 |3.

48. Vara JAF, Casado E, de Castro J, Cejas P, Belda-Iniesta C, GonzalezBaron M: PI3K/Akt signalling pathway and cancer. Cancer Treatment Reviews 2004, 30(2): 193.

49. Fleming TP, Saxena A, Clark WC, Robertson JT, Oldfield EH, Aaronson SA, Ali IU: Amplification and/or overexpression of platelet-derived growth factor receptors and epidermal growth factor receptor in human glial tumors. Cancer Res 1992 52(I6):4550-4553.

50. Lee Yl, Kwon YJ, Joo CK: Integrin-linked kinase function is required for transforming growth factor beta-mediated epithelial to mesenchymal transition. Biochem Biophys Res Commun 2004, 3 16(4):997-1001.

5I. Chagraoui J, Lepage-Noll A, Anjo A, Uzan G, Charbord P: Fetal liver stroma consists of cells in epithelial-to-mesenchymal transition. Blood 2003, 10 I(8):2973-2982.
52. Yanagisawa $\mathrm{K}$, Osada $\mathrm{H}$, Masuda A, Kondo M, Saito T, Yatabe $\mathrm{Y}$, Takagi K, Takahashi T, Takahashi T: Induction of apoptosis by Smad3 and down-regulation of $\mathrm{Smad} 3$ expression in response to TGF-beta in human normal lung epithelial cells. Oncogene 1998, I7(13): 1743-1747.

53. Danielpour D, Dart LL, Flanders KC, Roberts AB, Sporn MB: Immunodetection and quantitation of the two forms of transforming growth factor-beta (TGF-beta $I$ and TGF-beta 2) secreted by cells in culture. J Cell Physiol 1989, 138(1):79-86.

54. Reszka AA, Seger R, Diltz CD, Krebs EG, Fischer EH: Association of mitogen-activated protein kinase with the microtubule cytoskeleton. Proc Natl Acad Sci U S A 1995, 92(1 9):888I-8885.

55. Valenzuela DM, Groffen J: Four human carcinoma cell lines with novel mutations in position 12 of c-K-ras oncogene. Nucl Acids Res 1986, I4(2):843-85।. 